Universidad de Lima

Escuela de Humanidades

Carrera de Psicología

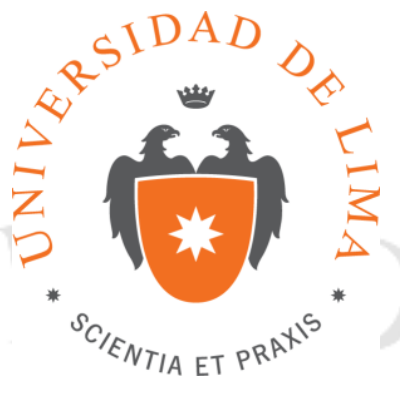

\title{
REPRESENTACIONES SOCIALES DE LA
}

LEUCEMIA EN PADRES DE NIÑOS

DIAGNOSTICADOS CON ESTA

ENFERMEDAD

DEL INSTITUTO NACIONAL DE ENFERMEDADES NEOPLÁSICAS

Tesis para optar el título profesional de Psicología

\section{Maria Paula Colmenares Morelli}

Código 20100297

Asesor

Fernando Ruiz Dodobara

Lima- Perú

Noviembre del 2016 


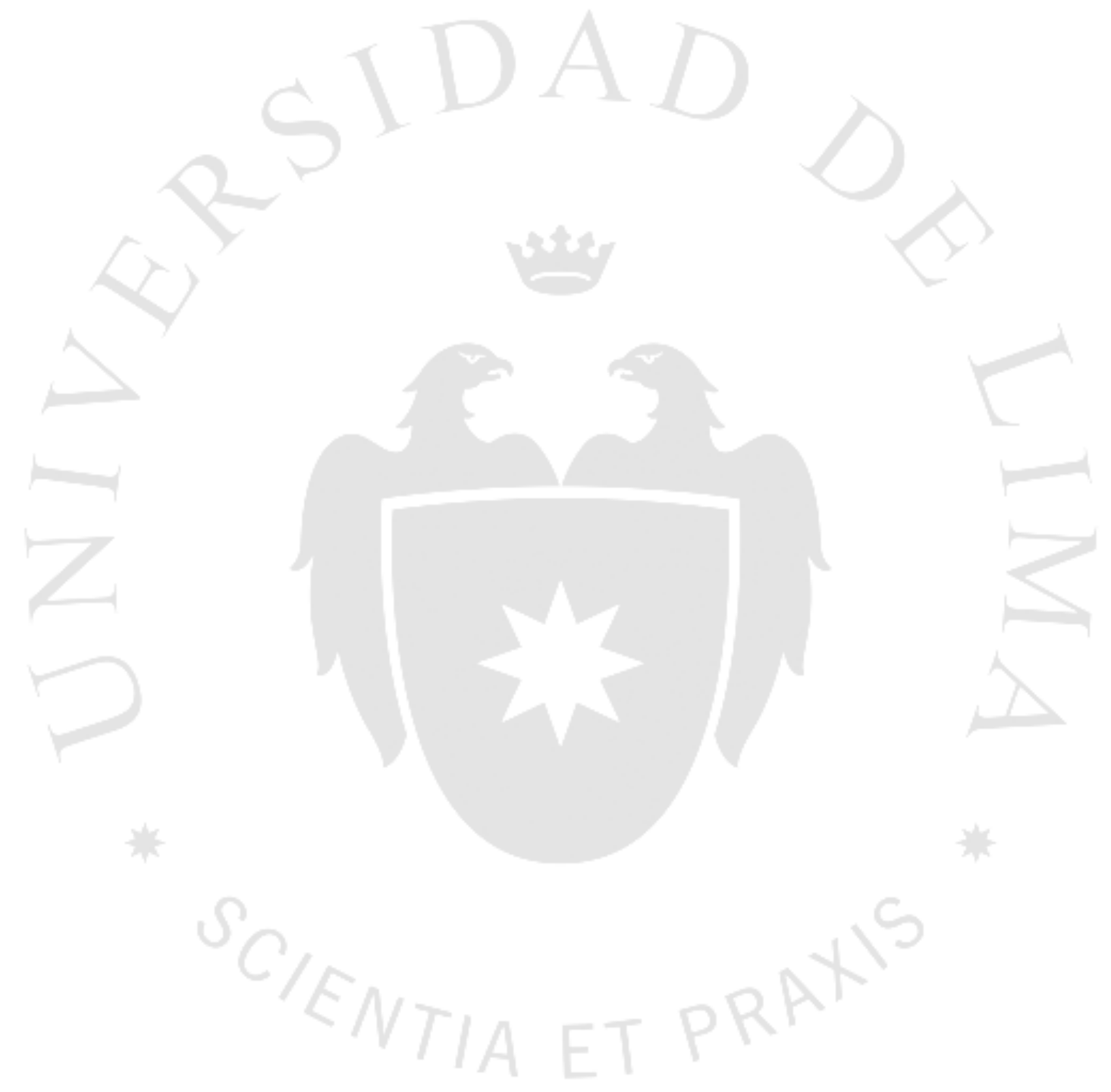




\section{REPRESENTACIONES SOCIALES DE LA}

LEUCEMIA EN PADRES DE NIÑOS DIAGNOSTICADOS CON ESTA ENFERMEDAD DEL INSTITUTO NACIONAL DE ENFERMEDADES NEOPLÁSICAS 


\section{RESUMEN}

La presente investigación explora las representaciones de la leucemia en padres de niños diagnosticados con esta enfermedad según el género, nivel de instrucción y lugar de procedencia de los mismos, en términos de identidad, causas, consecuencias, desarrollo y posibilidad de cura. Para ello, se entrevistó a 12 padres de niños hospitalizados en el Instituto Nacional de Enfermedades Neoplásicas que presentaban dicho diagnóstico. Se evidenciaron diferencias en términos de cómo esta enfermedad es conceptualizada, considerando que a mayor nivel de instrucción, los padres la vinculan en mayor medida con aspectos biológicos del propio organismo a diferencia de los padres con menor de instrucción, los cuales hacen mayormente referencia al factor ambiental. Asimismo, se observaron diferencias en relación a la capacidad de proyectar una situación futura, tomando en cuenta las repercusiones y limitaciones que la enfermedad de por sí trae consigo. De igual modo, se evidenció la presencia del sentimiento de culpa en madres y padres, siendo ello más frecuente en las primeras. También, un mayor desconocimiento sobre el tratamiento convencional en padres provenientes de la Selva peruana y una tendencia a buscar la causalidad de la enfermedad en elementos culturales.

Palabras clave: representaciones, leucemia, padres, niños.
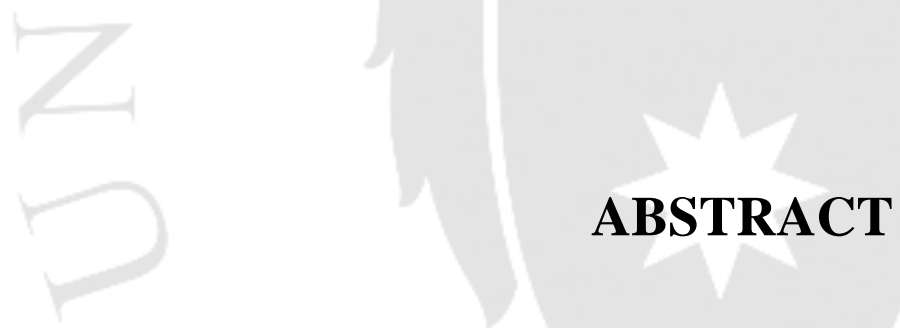

In this study, representations of leukemia in parents of children diagnosed with this disease by their gender, level of education and place of origin, in terms of identity, causes, consequences, development and possible cure are explored. For this, 12 parents of hospitalized children at Instituto Nacional de Enfermedades Neoplásicas that presented this diagnosis were interviewed. The results showed a wide variety in terms of how this disease is conceptualized, considering that parents with a higher level of education link it more closely with biological aspects than environmental aspects, which is mostly referred to by parents with a lower level of instruction. Also, variations between the ability to portray a future situation are illustrated, taking into account the implications and limitations that the disease itself entails. Besides, sense of guilt is found in both parents, with a higher intensity in mothers. Likewise, the lack of knowledge about conventional treatment in parents from the Peruvian jungle is shown, as does the tendency to seek the cause of the disease in cultural elements.

Key words: representations, leukemia, parents, children. 


\section{TABLA DE CONTENIDO}

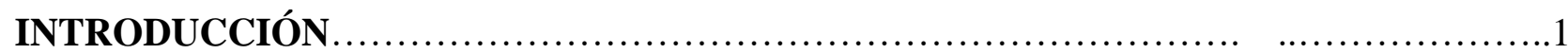

CAPÍTULO I: PLANTEAMIENTO DEL PROBLEMA .................................

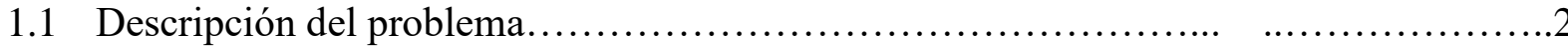

1.2 Justificación y relevancia................................................................

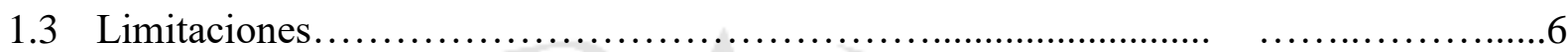

CAPÍTULO II: MARCO TEÓRICO.................................................

2.1 Fundamento de las representaciones......................... . ..............7

2.1.1 Naturaleza de las representaciones..................... ................7

2.1.2 Construcción de las representaciones...................... .................8

2.1.3 Complejidad de las representaciones..................... ................9

2.1.4 La representación social en el campo de la salud............................10

2.2 Las representaciones del cáncer.............................................12

2.2.1 Variables sociodemográficas influyentes en las representaciones del cáncer.........................................13

2.3 Impacto emocional de las representaciones de la enfermedad ...... ...............15

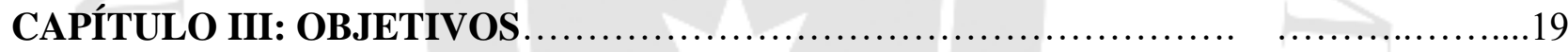

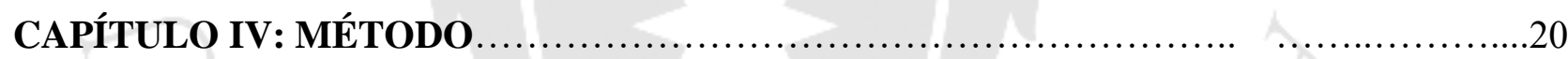

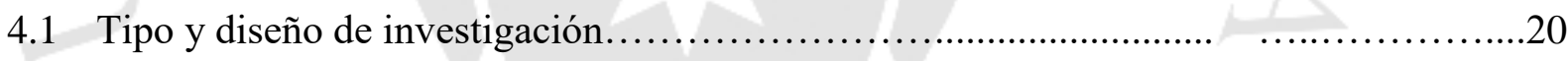

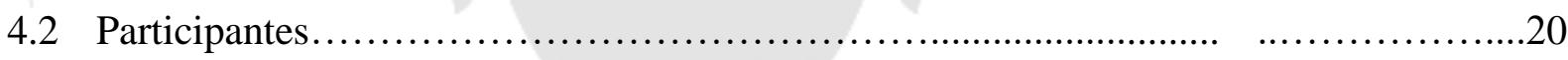

4.3 Técnicas de recolección de datos.....................................................22

4.4 Procedimiento de recolección de datos...............................................23

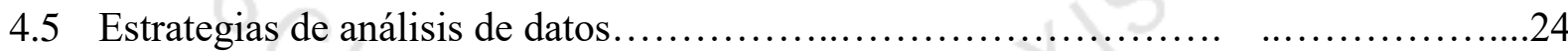

CAPÍTULO V: RESULTADOS ..................................................25

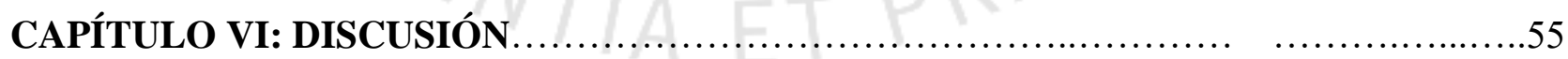

CAPÍTULO VII: CONCLUSIONES.................................................65

CAPÍTULO VIII: RECOMENDACIONES ............................................67

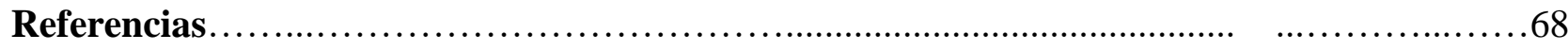

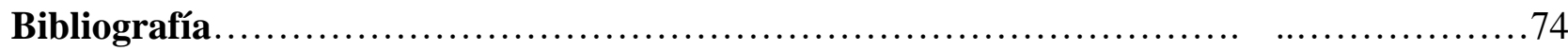




\section{ÍNDICE DE TABLAS}

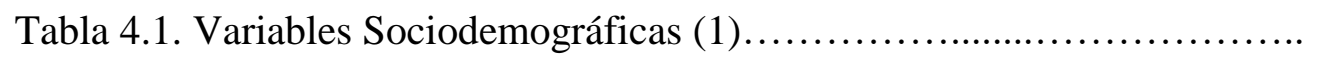

Tabla 4.2. Variables Sociodemográficas (2)

.22

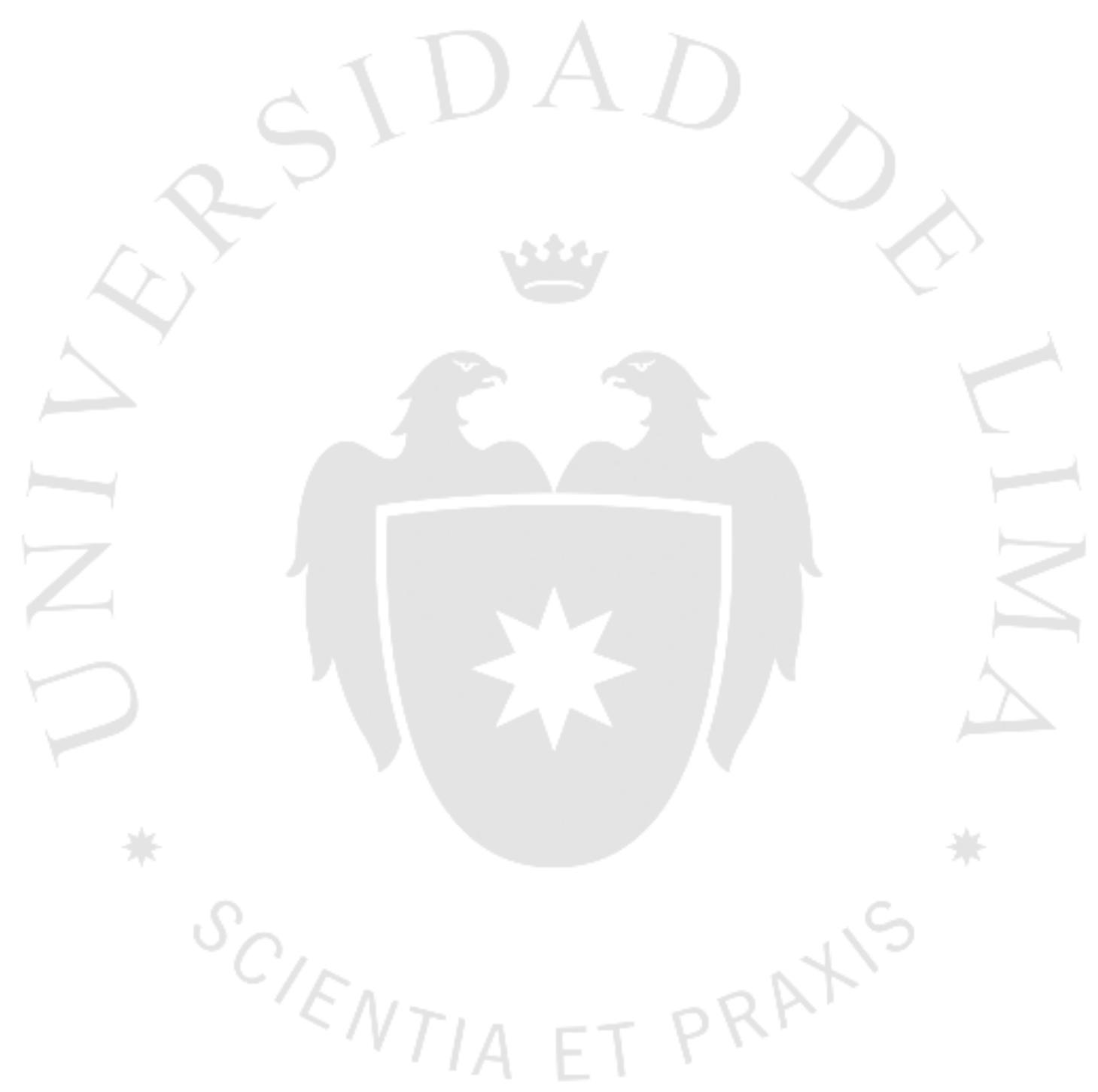




\section{ÍNDICE DE ANEXOS}

Anexo 1: Guía de preguntas.......................................................... 77

Anexo 2: Consentimiento informado.................................................. 78

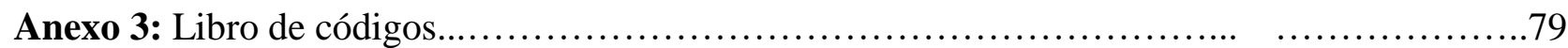

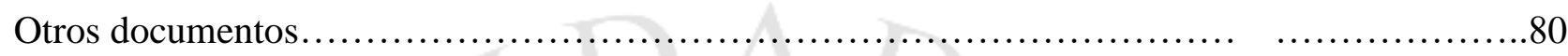




\section{INTRODUCCIÓN}

La presente investigación trata acerca de las representaciones sociales de la leucemia en padres de niños diagnosticados con esta enfermedad, en términos de identidad, causas, consecuencias, desarrollo y posibilidad de cura. A lo largo del trabajo, se relacionarán dichas variables con el lugar de procedencia, nivel de instrucción y género de los padres. A continuación se procederá a explicar aspectos del marco teórico, los cuales representan referencias para la misma, así como la metodología basada. Posteriormente, se pasará a describir los resultados obtenidos para dar fin con las conclusiones y recomendaciones del estudio. 


\section{CAPÍTULO I: PLANTEAMIENTO DEL PROBLEMA}

\subsection{Descripción del problema}

El cáncer constituye un problema de salud pública a nivel mundial, en la región de las Américas y en nuestro país, por su alta mortalidad como por la discapacidad que produce, pues representa una de las principales causas de muerte (Ministerio de Salud del Perú, [MINSA], 2013).

A nivel mundial se diagnostican aproximadamente 12.7 millones de casos nuevos cada año y se prevé que para el 2030 esta cifra se elevará a 21.3 millones, teniendo un mayor impacto en las poblaciones de menores recursos (MINSA, 2013).

De acuerdo a estimaciones realizadas por la Agencia Internacional de Investigación en Cáncer, se estima que la incidencia acumulada de cáncer en nuestro país es de 157.1 casos por 100,000 habitantes, siendo ésta notablemente más alta en mujeres que en varones (174.9 por 100,000 versus 140.9 por 100,000), considerando que a nivel de toda la población (de aproximadamente 30 millones de habitantes) cada año se diagnostican más de 45,000 casos nuevos. Y aunque la incidencia general del cáncer es menor en América Latina que en Europa o los EE UU, la mortalidad sigue siendo mayor (MINSA, 2013).

En base a la estimación de casos nuevos de cáncer por año para Lima Metropolitana y el país en general, realizado por el INEN, se ha observado un incremento en el número de casos, lo cual permite suponer que en el 2025, la cifra aumentará a 51,695 (MINSA, 2013).

El incremento de los casos de cáncer en nuestro país está vinculado a determinantes como la transición demográfica, la transición epidemiológica, la pobreza, la urbanización, los cambios en la alimentación, el género, la raza/etnia, entre otros, debido a que representan circunstancias en las cuales las personas viven, crecen y se desarrollan (MINSA, 2013).

La Vigilancia Epidemiológica de Cáncer notificó 3,801 casos de cáncer en niños diagnosticados en el período 2006-2011, lo que corresponde al 3.5\% de 
todos los cánceres notificados en dicho período. El 56.4\% implicó al sexo masculino; mientras que el $43.6 \%$ al femenino. Y, en relación a las edades, cerca de la mitad de los cánceres notificados se presentaron en menores de cinco años (47.4\%) (MINSA, 2013).

De acuerdo a un artículo de la Agencia Peruana de Noticias, en el INEN se atienden anualmente unos 2,000 infantes, de los cuales alrededor de 600 son casos nuevos ("Plan Esperanza brinda atención oncológica integral a niños con cáncer del INEN", 2015), siendo las neoplasias más frecuentes las del sistema hematopoyético y retículo endotelial (44.2\%) seguidos de las neoplasias del encéfalo (8.0\%) y las del ojo y anexos (7.8\%), que en conjunto representan el $60 \%$ de los cánceres notificados en menores de 15 años (MINSA, 2013; Instituto Nacional de Enfermedades Neoplásicas [INEN], 2014).

Según datos del MINSA del 2015, a este nosocomio acuden personas afiliadas en su mayoría al Seguro Integral de Salud (SIS) y procedentes de las diversas regiones del Perú, siendo la región del Norte, más específicamente de Lima-Callao, la que predomina con un $17.5 \%$, siguiendo con la del Sur con $11.2 \%$, la del Centro con $6.8 \%$ y la de la Selva con un $4.7 \%$ (INEN, 2015a).

En base al conocimiento de dichos indicadores, resulta importante explorar y considerar el significado que el paciente y su entorno construyan acerca de la condición médica que se padezca, dada su repercusión en el tipo de afrontamiento que se tenga frente a la enfermedad, en el grado de adherencia al tratamiento que se logre y en la comunicación que se instaure con el personal de salud.

En el caso de los niños, los padres al ser los intermediarios entre el personal médico y sus hijos, y el principal agente en la toma de decisiones de la enfermedad de los mismos, es imprescindible identificar las representaciones que posean de la enfermedad para así contar con un punto de referencia para explicarles en términos que les resulten familiares la enfermedad de sus hijos y el tratamiento a seguir. Ello permitirá que comprendan con mayor cabalidad el diagnóstico y el tratamiento médico. De esta manera, los padres tendrán una mayor confianza en el personal de salud y en la medicina convencional, siendo más adherentes y constantes ante las recomendaciones que estos les impartan. 
Además, dado que la comprensión de la realidad se forja interpersonalmente, los significados que tengan los padres influirán y servirán de referente en el modo cómo sus hijos perciban la enfermedad, así como también en su nivel de confianza ante los diferentes agentes del contexto intrahospitalario, lo cual conducirá a una mejor adaptación a lo largo de todo este proceso (Neimeyer y Neimeyer, 1996 citado en Ruda, 2001; Ortigosa y Méndez, 2000 citado en Silva, 2012; Tremolada et al., 2011; Guana, 2011).

Resulta importante mencionar que los significados que cada uno construya pueden variar, dado que estudios han demostrado que en relación al cáncer en general, tanto el lugar de procedencia, el género, la edad, el nivel socioeconómico y el nivel de instrucción son variables que influyen en la representación que se posea del mismo, en términos de identidad, causalidad, consecuencias, línea de tiempo y posibilidad de cura (Ruda, 2001; Llinares, Benedito y Piqueras, 2010; Castaño y Palacios- Espinosa, 2013).

Es por ello que es de gran relevancia para el trabajo conjunto que el personal de salud conozca acerca de las representaciones que tengan los padres de los pacientes acerca de la enfermedad, además de las características psicosociales, la historia del tratamiento y las expectativas que posean de la misma, dado que la relación médico-paciente-familia, al estar mediada por historias individuales y sociales distintas, puede traducirse en una relación asimétrica y en algunos casos conflictiva, dado el choque de creencias, características y expectativas distintas (Domínguez, 2012).

Con ello no solo hace alusión al personal médico, sino también a los enfermeros, psicólogos y demás especialistas que trabajan con el paciente y con la familia, pues solo así se podrá tener una aproximación más adecuada para enrumbar el tratamiento y fomentar su adherencia, brindándoles una atención más personalizada y basada en las necesidades que presentan. De este modo, el soporte brindado será más adecuado y permitirá disminuir sus niveles de ansiedad (Ocampo, Peñaloza, Sarmiento y Hernández, 2014; Trujano, Vega, Nava y Saavedra, 2011; Goisin, 2014).

Es por ello que resulta imprescindible estudiar qué representación tienen los padres sobre la enfermedad, en este caso de la leucemia, la cual es la 
enfermedad más común en los niños, a fin de explorar, describir y comprender sus experiencias en relación a la misma. Ello permitirá descubrir los elementos en común de tales vivencias y/o elaboraciones, a fin de brindar una línea base para el trabajo interdisciplinario en el ambiente hospitalario, considerando además que ellos representan una influencia directa en cómo sus hijos ven e interpretan su condición médica actual (Hallford, 1993; Giraldo-Mora, 2009; Ruda, 2009; Llinares, Benedito y Piqueras, 2010; Castaño y Palacios- Espinosa, 2013).

Por todo ello, el presente estudio pretende responder la siguiente pregunta ¿Cuáles son las representaciones sociales de la leucemia en padres de niños diagnosticados con esta enfermedad del Instituto Nacional de Enfermedades Neoplásicas?

\subsection{Justificación y relevancia}

La presente investigación es relevante tanto a nivel teórico como metodológico.

A nivel teórico, este estudio pone en práctica la teoría de las representaciones sociales al área de la psicooncología, al considerar que estas son construcciones fuertemente orientadas por elementos culturales que organizan y orientan la manera de pensar y actuar de las personas en relación a los diferentes entornos. Por otro lado, continúa el trabajo de la línea de investigación que estudia las representaciones del cáncer, lo cual contribuye a la realización del trabajo clínico en el campo de la psicooncología.

A nivel metodológico, identifica categorías relevantes de análisis que sirven como guía para una comprensión más profunda de las representaciones que tienen los padres de la leucemia, considerando que ello fomentará una interacción más adecuada con el personal médico y demás especialistas. Ello, a su vez, permitirá lograr una adecuada adherencia al tratamiento y una mejor adaptación al ambiente intrahospitalario en los niños, considerando que los padres son parte importante del nexo interdisciplinario y una significativa fuente de soporte en sus hijos, más aún cuando se ha encontrado que variables como el género, el lugar de procedencia y el nivel de instrucción influyen en la 
representación que tengan los padres acerca del cáncer, al estar inmersos en un contexto social (Ruda, 2001; Caballero, 2012; López-Huerta, Álvarez-Bermúdez y González-Romo, 2012; Mejía, 2013; Caldas, 2014).

\subsection{Limitaciones}

Algunas limitaciones que se presentan en este estudio son la disponibilidad de los padres para ser entrevistados y la dificultad de los mismos para conversar acerca de la enfermedad que padece su hijo, dado que ello conlleva sentimientos de angustia y tristeza. 


\section{CAPÍTULO II: MARCO TEÓRICO}

\subsection{Fundamento de las representaciones}

Los seres humanos construyen representaciones sobre su entorno, la naturaleza, la sociedad y sobre sí mismos. Estas se organizan en estructuras conceptuales, procedimentales y actitudinales que le dan sentido a la interioridad y exterioridad de su medio, con miras al dominio, la intervención, el control y la transformación del mismo (Arbeláez, 2002).

\subsubsection{Naturaleza de las representaciones}

Jodelet (1991) define la representación social como una forma de conocimiento, llamada de sentido común, socialmente elaborada y compartida, que apunta a un fin práctico de organización, de dominio del ambiente y de orientación, que establece una visión consensuada de la realidad dentro de un marco social o cultural dado, al suponer una actividad de apropiación y de elaboración psicológica y social. Es por ello que constituye una modalidad de pensamiento práctico, orientado hacia la comunicación, la comprensión y el dominio del entorno social, material e ideal.

La representación social es siempre representación de algo (objeto) y de alguien (sujeto), pues implica la simbolización y la interpretación de los mismos, a través de sistemas de codificación proporcionados por la sociedad, así como la proyección de valores, deseos, necesidades, intereses y aspiraciones sociales. Este conocimiento social, si bien se constituye a partir de las experiencias personales, también surge de la información, el conocimiento y los modelos de pensamiento que recibimos y transmitimos a través de la comunicación, de los marcos de aprehensión que proporciona el bagaje cultural, y de los códigos, valores e ideologías relacionados con las posiciones y pertenencias sociales específicas, los cuales se plasman en la tradición y la educación, dado que son socialmente elaborados y compartidos. 
Por tanto, se entiende que es a través del contexto concreto en que se sitúan los individuos y grupos como interviene el plano social (Jodelet, 1991).

\subsubsection{Construcción de las representaciones}

Moscovici (2001) plantea que las representaciones sociales permiten crear información nueva en relación al mundo en el que vivimos, dado que su función es familiarizarnos con lo extraño, de acuerdo a la cultura en la que estamos inmersos o a la que pertenecemos, ya sea abstrayendo como creando nuevos significados, dándole forma así a la conciencia colectiva.

La aparición de una situación nueva o bien de un fenómeno desconocido o de un evento inhabitual favorece el surgimiento de una representación social, dado que la condición de novedad hace que la información del objeto sea limitada, incompleta y desarticulada, y por tanto dispersa para los diferentes grupos sociales implicados. Esta, al alterar el curso habitual de las cosas, motiva una actividad cognitiva intensa que pretende comprender, dominar e incluso defenderse del objeto, a través de una puesta en común de informaciones, creencias, hipótesis o especulaciones que llevan a la emergencia de posiciones predominantes en los diferentes grupos sociales (Moscovici, 1961 en Rateau y Lo Monaco, 2013).

La aparición de dichas posiciones predominantes da cuenta, entonces, del nacimiento de un consenso que es facilitado por el hecho de que los individuos tratan la información sobre el objeto o la situación de forma selectiva, focalizándose sobre el aspecto particular en función de las expectativas o las orientaciones de sus grupos de pertenencia, lo cual llega a darse mediante los procesos de objetivación y anclaje. En el primero de ellos, el nuevo objeto pasa a ser simplificado, traducido en imágenes y esquematizado, creando un núcleo figurativo, el cual orienta los juicios y conductas de las personas. En el segundo, se coloca a los objetos en un contexto familiar, lo cual hace que encuentren su lugar en el sistema de pensamiento preexistente de los individuos y de los grupos, 
dando espacio a diversas interpretaciones, en relación a una implicación de identidad (Moscovici, 1961 en Rateau y Lo Monaco, 2013).

Jovchelovitch (2007) plantea que dado que estos nuevos saberes son producidos y acomodados en el tejido social y se orientan hacia la construcción y la transformación de los saberes sociales producidos en la vida cotidiana, en relación a diferentes contextos sociales, son un espacio entre el individuo y la sociedad, al tomar en cuenta los objetos, sujetos y actividades.

\subsubsection{Complejidad de las representaciones}

Dado que las representaciones no son reproducciones verídicas de los hechos del mundo, sino elaboraciones para los grupos sociales que sirven como recursos para comprender su vida cotidiana particular, pueden ser distintas e incluso opuestas, pues son fruto de su interacción con el medio que le rodea y pueden coexistir de manera dinámica. A ello, Moscovici lo llama polifasia cognitiva (Moscovici, 1961 en Wagner y Hayes, 2011).

En base a ello, se plantea que el individuo es capaz de utilizar diferentes registros lógicos en su dominio, dado que se relaciona con perspectivas, información y valores distintos. Es por ello que puede sobrevivir en una dinámica en la que coexisten interferencias y similitudes de diferentes modalidades de conocimiento correspondientes a relaciones especificas entre el hombre, el contexto y los conocimientos derivados de ello, como puede ser la ciencia, el sentido común, la religión y el conjunto de ideologías que posea (Jovchelovitch, 2007).

En ese sentido, se trataría de la coexistencia de contenidos heterogéneos en la que conviven imágenes, conceptos, explicaciones, pertenecientes a niveles cognitivos de distinta riqueza, complejidad y origen, influidos además por distintos factores, fuertemente vinculados a la experiencia social del sujeto (Lombardo y Monchietti, 2015).

Por lo tanto, la transformación del conocimiento estaría caracterizada por cambios en el sistema que suceden fundamentalmente 
por transformaciones de naturaleza histórico-social y cultural, dado que los sujetos que integran diferentes grupos sociales operan una selección específica de informaciones y saberes sobre un objeto social, lo cual hace que integren aspectos que le resulten significativos y rechacen aquellos que no lo sean (Lombardo y Monchietti, 2015).

\subsubsection{La representación social en el campo de la salud}

Las representaciones de salud y enfermedad, al estar basadas en la interacción social, son formas de concebir y de dar sentido a un fenómeno e influyen en la forma en que la persona y los grupos se relacionen con este (Tavera, 2012).

De este modo, las representaciones sociales de una enfermedad determinan la reacción de la sociedad y de cada individuo frente a ella, puesto que son imágenes que condensan un conjunto de significados; es decir, sistemas de referencia que permiten interpretar lo que sucede e incluso dar un sentido a lo inesperado, al ser categorías que sirven para clasificar las circunstancias, los fenómenos y a los individuos que los rodean (Jodelet, 1986).

En cuanto al cáncer, las representaciones sociales estarían determinadas, entonces, por las creencias culturales que se forman en torno al significado de padecer esta enfermedad y a las implicancias que conlleva, lo cual influiría en la percepción y en la actitud de los pacientes mismos y de la población en general (Gil, 2000), puesto que, como dice Gallego (1995), estas representaciones al organizarse en estructuras conceptuales, procedimentales y actitudinales le dan sentido a la interioridad y exterioridad del entorno, buscando así controlarlo, dominarlo y transformarlo.

Es por ello que frente a una realidad como el diagnóstico de cáncer, la persona buscará interpretar la situación con el fin de encontrar el propósito y significado a estos acontecimientos para luego enfrentar el problema que se le plantea (Ruda, 2001). 
De este modo, dependiendo de la interpretación que realice de los estímulos, la persona, presentará una conducta activa ante su enfermedad y construirá un modelo de la misma, articulándola en torno a cinco dimensiones básicas: identidad, causa, consecuencias, línea de tiempo y cura/control (Andrykowski et al., 2008; Hetje, Lechner y Vollink, 2008; Rozema, Vollink y Lechner, 2008; Heidrich, Phelan y Rhea, 2009; Evans y Norman, 2009).

La identidad se referirá a la etiqueta (nombre, diagnóstico) que le coloca a la enfermedad y al conjunto de síntomas experimentados; la causa, a las creencias sobre el origen de su enfermedad o condición; las consecuencias, a las ideas ligadas al impacto y secuelas de la enfermedad y sus síntomas; la línea de tiempo, a las percepciones acerca del curso de la misma; y la cura/control, a las creencias acerca de la capacidad para poder controlar el síntoma mediante el tratamiento (Leventhal, Meyer y Nerens, 1980; Hale, Treharne y Kitas, 2007; Rodriguez y Neipp, 2008).

Estas dimensiones han sido estudiadas, en el campo de la salud, dentro de un modelo teórico denominado "Modelo de sentido común de la representación de la enfermedad", propuesto por Leventhal, el cual asume que cada persona tiene creencias de sentido común o representaciones acerca de la enfermedad, las cuales pueden ser definidas como aquellas creencias que se organizan y dan sentido al entorno en el que viven, asociándolas, en este caso, a la afección que padecen (Leventhal et al., 1980), considerando, a su vez, la influencia de la experiencia personal, la experiencia vicaria y las respuestas sociales en su concepción (Arbeláez, 2002; Andrykowski et al., 2008; Caldas, 2014).

En investigaciones anteriores, se ha encontrado que en lo que se refiere de manera específica a las representaciones del cáncer, éstas continúan teniendo una connotación negativa, pues se encuentran ligadas a una enfermedad grave, en donde surgen asociaciones de muerte, incurabilidad, impotencia, dolor, mutilación, terror, sufrimiento, desesperación, tristeza y devastación, las cuales repercuten en la actitud $\mathrm{y}$ en el comportamiento que se tenga hacia ella (Iglesias, Fabelo y 
Miranda, 2005; Llinares, Benedito y Piqueras, 2010; Ruda, 2009; Giraldo-Mora, 2009; Castaño y Palacios- Espinosa, 2013).

\subsection{Las representaciones del cáncer}

En cuanto a la representación del cáncer, esta enfermedad suele ser vista de diversas formas: como una herida interna o externa, una bola, un virus o células malignas que habitan dentro de ellos. Como un animal que se adhiere a la piel, como un mal oculto silencioso, destructivo que se desplaza y es capaz de migrar. En ocasiones, la enfermedad es interpretada como un dibujo animado, una mancha. Para otros, es vista como una enfermedad de rápida reproducción a partir del cual se hacen diversas evaluaciones generándoles carga afectiva, impidiendo, en algunas situaciones, imaginarla, puesto que suele ser vista como generador de desgaste corporal y malestar general, que interrumpe la productividad y que produce alteraciones del estado de ánimo en términos de desgano, amargura, tristeza, incertidumbre, confusión, miedo, impotencia, resignación, depresión y sensación de pérdida de control (Ruda, 2001; Castaño y Palacios-Espinosa, 2013; Caldas, 2014).

En relación a la causalidad, Vega (2011 citado en Monteza, y Vera, 2014), señala que el origen de los procesos oncológicos es una fuente importante de las representaciones sociales, pues la búsqueda de la causalidad es un aspecto lógico del pensamiento social, sobre todo cuando se trata de un objeto o acontecimiento nuevo, acerca del cual no se tiene conocimiento. Es por ello que en los casos en que la enfermedad está acompañada de incertidumbre, como ocurre con las neoplasias malignas, es frecuente que las personas busquen comprender las causas e implicancias de los acontecimientos que presencian y experimentan como un modo de ganar control sobre la situación (Nouvillas y Huici, 1990).

En diversas investigaciones, se ha encontrado que el cáncer es comúnmente asociado a factores hereditarios y congénitos. No obstante, también al estilo de vida insano, como la mala alimentación, el poco descanso, el desvelo, la falta de ejercicio, el consumo de alcohol y tabaco y la vida sexual desordenada. Así, como al estrés y depresión. Y en ocasiones, al contagio, los 
golpes, el maltrato físico, el comportamiento disruptivo y la contaminación e inhalación de sustancias tóxicas (LLinares et al., 2010; Murray, 1997 citado en Castaño y Palacios-Espinosa, 2013; Caldas, 2014).

En cuanto a la leucemia específicamente, LLinares et al. (2010) encontraron que las representaciones son variadas, puesto que las personas atribuyen su origen a factores externos al referir como causalidad los estilos de vida, accidentes e infecciones ocasionadas por virus o bacterias que ingresan al organismo; y a factores internos, al referirse a causas genéticas. No obstante, también es atribuida a una causa inexplicable.

Todo ello se relaciona con la postura de Moscovici (1961), al mencionar que la representación es un campus organizado de conocimientos y una de las actividades psíquicas gracias a las cuales las personas hacen inteligible la realidad física y social.

De este modo, los prototipos de enfermedad influirán sobre los estados de ánimo y en las percepciones individuales que se tengan de salud y bienestar, llegando a predecir el malestar psicológico, en tanto se relacionan con estados de ansiedad y depresión, considerando que las representaciones de enfermedades crónicas suelen estar plagadas de una afectividad negativa y asociadas a un proceso doloroso, largo y sufriente (Tavera, 2012; Caldas, 2014).

Tal como señala Jodelet (1993 citado en Huapaya, 2004), las representaciones no solo contienen información organizada y jerarquizada, sino también una dimensión evaluativa y actitudinal que orienta las conductas relacionadas al objeto representado (Tavera, 2012).

\subsubsection{Variables sociodemográficas influyentes en las} representaciones del cáncer

Soler (1996, citado en Caballero, 2012), alude que en relación al género, las madres al ser quienes pasan la mayor cantidad de tiempo acompañando a sus hijos en sus hospitalizaciones y tratamientos, tienen un mayor involucramiento afectivo, lo cual se traduce en una mayor atención en los cambios físicos y emocionales que experimentan sus hijos, dado que son 
quienes se implican de manera más directa con la carga emocional que conlleva toda la situación de enfermedad.

Ruda (2001) alude que es interesante observar el impacto que al parecer tienen las variables grado de instrucción/edad y experiencia de vida en los padres en la decodificación de la gravedad implícita de una enfermedad, al demostrar que las variables socio-económicas y culturales, así como la presencia de antecedentes familiares de neoplasias malignas, se vinculan en mayor medida a contenidos referidos a los dolores físico y emocionales, entre los cuales se encuentra la depresión, la angustia, el miedo y el sentimiento de culpabilidad.

Dicha autora, asimismo, identificó que el nivel socioeconómico guarda relación con el tipo de representación que poseen los padres. En el grupo con mejor situación económica y mayor nivel educativo se vio que los padres atribuían como factor causal las variables internas (el factor hereditario, la condición del propio organismo y el caos corporal). Y que dentro de lo que se refiere al caos corporal, la representación de ataque al cuerpo, fue referida en mayor medida cuando se referían a la leucemia, a diferencia de otras enfermedades cancerígenas.

Por otro lado, Mejía (2013) encontró que el no haber completado los estudios escolares, también puede dificultar la comprensión de las explicaciones sobre la naturaleza de la enfermedad, su tratamiento y las indicaciones sobre el cuidado del niño fuera del hospital, dado que ello suele desencadenar inseguridad en sus desempeños posteriores.

Respecto a la condición migratoria de los padres, además de conllevar la pérdida de soporte social para muchos, esta suele asociarse a mayores sentimientos de tristeza y aislamiento, dado que la prolongación del tiempo distantes de la familia, contribuye a mayores niveles de ansiedad y a menor aceptación frente a la enfermedad (Rojas, 2005; Mejía, 2013).

Por lo tanto, este conjunto de factores, al guardar relación con la conducta, pueden influir en el afrontamiento que se tenga a la enfermedad, en su adaptación física, en el ajuste mental y psicológico, en la aceptación de su enfermedad, en su adherencia al tratamiento y en la adopción de estilos de vida 
saludables, puesto que la percepción que se tenga sobre ella en términos de conceptualización y consecuencias repercute en su salud física y mental, así como en sus niveles de estrés y malestar subjetivos (Rozema et al., 2008; Moldovan, 2009; Caldas, 2014).

\subsection{Impacto emocional de las representaciones de la enfermedad}

Una enfermedad grave, de por sí, en algún miembro de la familia representa una fuente de estrés, no solo por la incertidumbre y la ambigüedad propia de los episodios de la enfermedad, sino por la necesidad de mayores recursos económicos y por la perturbación de la red de interacciones internas que esta genera (Leventhal, Leventhal y Van Nguyen, 1985 citado en Rodríguez y Neipp, 2008; López-Huerta et al., 2012).

En el caso de un niño con una enfermedad oncológica, su condición especial de crianza implica desafíos para la parentalidad, adicionales a las tareas fundamentales de proveer los cuidados básicos, establecer límites y control y asegurar y fortalecer su desarrollo, pues a ello se le suma la función de ser una importante fuente de soporte, práctico y emocional para su hijo enfermo (Ruda, 2009; Sloper, 2000). Grau y Espada (2012) constatan cómo la enfermedad altera las distintas relaciones de la dinámica familiar, ya sea en la relación con la pareja (en la redistribución de roles y responsabilidades), con los otros niños y con el niño enfermo (en términos de modificaciones en el sentido de independencia y disciplina) y en relación a la familia extensa.

El recibir la noticia de la enfermedad se ha asociado con elevados niveles de depresión, ansiedad y estrés global para padres y madres (Yeh, 2001; Mejía, 2013), así como con intensos sentimientos de ansiedad como ideas de peligro potencial que amenazan las metas y valores importantes para ellos, entre ellas la salud e integridad, y la vida misma (Flores, 1999 citado en Ruda, 2001). Los sentimientos de angustia, hostilidad, autocensura y culpa hacen que se sientan a menudo responsables de la enfermedad de su hijo y cuestionan su capacidad para protegerle (Grau, 2002).

Con el paso del tiempo, los sentimientos de malestar suelen seguir presentes, así como las dificultades para dormir, los sentimientos de soledad y 
melancolía, las somatizaciones, la baja autoestima y los sentimientos de pérdida de control como padres y en su vida personal (Boman, Lindahl y Björk, 2003; Brown, Madam-Swain y Lambert, 2003; Sloper, 2000; Mejía, 2013).

Es por ello que entre los factores emocionales que influyen en el curso del cáncer infantil, el rol del estado emocional de los padres cobra cada vez mayor importancia, dado que de por sí, los aspectos médicos, como los psicoemocionales y sociales que implican la enfermedad constituyen una importante fuente de estrés para ellos (Mejía, 2013).

Estudios en madres norteamericanas revelaron que el estrés en las madres demostró cumplir un papel moderador entre la percepción de elevadas demandas de cuidado de esta enfermedad y el desarrollo de problemas emocionales en los niños, lo cual indica que un nivel bajo de estrés previene los problemas de ansiedad y depresión en niños oncológicos (WolfeChristensen et al., 2010).

Inicialmente, los padres suelen reaccionar con sentimientos de ansiedad, ira, hostilidad, temor a la muerte, soledad, culpa e incredulidad, además de sensación de abandono y fracaso. Factores psicosociales pueden complicar el afrontamiento y repercutir sobre el bienestar del niño y de su familia, dentro de los cuales se ubica la carga económica percibida concerniente a los costos de la enfermedad y su tratamiento, los problemas laborales relacionados con la necesidad de tener tiempo suficiente para cuidar al niño enfermo, la disponibilidad de soporte social, la comunicación y cohesión familiar, la calidad de la relación conyugal, la historia personal y afectiva de cada uno de los padres, la edad y genero del niño, la etapa del ciclo vital de la familia, la comprensión acerca de las implicaciones de la enfermedad y el tratamiento, el tipo de vinculación afectiva de la familia, escolaridad de los padres y las tensiones concurrentes (Guana, 2011).

Generalmente, el sufrimiento en las familias en las cuales uno de sus miembros padece de cáncer depende de las creencias y el significado atribuido a la enfermedad y al tratamiento; además de las experiencias anteriores relacionadas con la enfermedad y la muerte, el estadio del cáncer, los recursos 
económicos, el soporte social y el sistema de relaciones familiares, especialmente en la forma como organizan el cuidado, la comunicación y la afectividad (Castaño, Krikorian, Vargas y Vélez, 2009).

Ajuriaguerra y Macelli (1987), aluden que los padres, con tal de encontrar una explicación acerca de la aparición de la enfermedad, crean ciertas teorías etiológicas, ya sea asumiendo todo el peso de la transmisión de la enfermedad por parte de uno de ellos o negando toda la carga hereditaria. Cuando los sentimientos de responsabilidad y culpa son difíciles de manejar por los padres, llegan a concebir la enfermedad como producto de la negligencia o manifestación de un amor insuficiente (Perrichi, 1986), dado que como refiere Weiner (1992) en la teoría de la atribución, la culpa es experimentada cuando la causalidad de un fenómeno es atribuido a variables internas y controlables.

Nouvillas y Huici (1990) afirman que ante esta falta de certeza, los padres tienden a ver la realidad desde su propia perspectiva, a la que se le adjudicarán un significado personal, e influirá en su comportamiento hacia la situación de enfermedad. Es por ello que el rol que juegan los padres en la experiencia de hospitalización es fundamental en lo que se refiere a la ansiedad, los trastornos del sueño, la información y las alteraciones emocionales y conductuales del niño (Ortigosa y Méndez, 2000 citado en Silva, 2012).

De modo que, como menciona Hallford (1993), las representaciones que los padres de niños afectados por algún proceso oncológico construyen sobre dicha enfermedad cumplen un rol de suma importancia, tanto en términos personales como en la relación que se establece con su hijo enfermo, considerando que la comprensión de la realidad se forja interpersonalmente (Neimeyer y Neimeyer, 1996 citado en Ruda, 2001).

Es así como Calman (1982) remarca al respecto el poder de la comunicación, tanto verbal como no verbal, pues observa que muchas veces los temores de familiares, amigos, enfermeras y doctores se convierten también en los miedos del paciente hasta el punto que puede llegar a afectar críticamente la aproximación que este último tiene hacia su enfermedad y las 
representaciones que el mismo paciente desarrolle acerca de su padecimiento (Ruda, 2001). En base a ello, Tremolada et al. (2011), proponen que un mejor conocimiento de las opiniones y expectativas con respecto a la calidad de vida de sus hijos durante los primeros tratamientos para la leucemia pediátrica puede facilitar los procesos de comunicación en el hospital y puede contribuir a proporcionar una mejor atención psicosocial para el niño.

Por tanto, la adherencia al tratamiento y las representaciones de la enfermedad estarían influenciadas por el tipo de relación que se establece entre el médico o el personal de salud, los padres y el niño, dado que ello impactará en el modo en que se produzca la adaptación a la enfermedad (Guana, 2011). 


\section{CAPÍTULO III: OBJETIVOS}

- Identificar las representaciones sociales de la leucemia en padres de niños diagnosticados con esta enfermedad del Instituto Nacional de Enfermedades Neoplásicas en términos de identidad, causas, consecuencias, desarrollo y posibilidad de cura.

- Describir las representaciones sociales de la leucemia en padres de niños diagnosticados con esta enfermedad del Instituto Nacional de Enfermedades Neoplásicas en términos de identidad, causas, consecuencias, desarrollo y posibilidad de cura.

- Explorar las representaciones sociales de la leucemia en padres de niños diagnosticados con esta enfermedad del Instituto Nacional de Enfermedades Neoplásicas, en relación al género, lugar de procedencia y nivel de instrucción de los mismos. 


\section{CAPÍTULO IV: MÉTODO}

\subsection{Tipo y diseño de investigación}

El presente estudio tiene un alcance exploratorio-descriptivo. Exploratorio debido a que, como alude Hernández, Fernández y Baptista (2010), se trata de un tema con poca información al respecto, en el que se busca identificar conceptos promisorios y prepara el terreno para nuevas investigaciones; y descriptivo, en la medida de que se exponen las características propias de las representaciones, plasmadas en diversas categorías de análisis. De igual modo, corresponde a un diseño fenomenológico, dado que busca recoger y describir las experiencias vividas de los padres con hijos diagnosticados con leucemia. Tal como señala Rodríguez, Gil y García (1999), este es un método que busca explicitar la esencia de las experiencias de los actores, siendo la descripción de los significados vividos lo fundamental.

\subsection{Participantes}

Se empleó un muestreo de tipo intencional y por oportunidad, dado que la elección de los sujetos dependió de la disponibilidad de los entrevistados y de la posibilidad de tener un acceso directo a ellos (Hernández, Fernández y Baptista, 2014).

En ese sentido, la muestra estuvo constituida por 12 padres de 9 niños diagnosticados con leucemia. Solo en el caso de 3 niños se entrevistó a ambos progenitores, en 4 casos se contó con la participación exclusiva de la madre y en 2 casos, el padre asistió solo a la entrevista.

Al seleccionar la muestra, se consideró que el paciente se encontrara en la etapa de inducción al tratamiento y esté hospitalizado en la institución en un tiempo mayor a una semana. Así como también, que el niño tenga entre 0 y 12 años y se encuentre acompañado, por lo menos, de uno de sus padres durante su internamiento. 
Cabe mencionar que el número total de casos se trabajó bajo el criterio de saturación, es decir, se entrevistó hasta que la información recabada se tornó repetitiva y no se obtuvo nueva información, dado que en la indagación cualitativa, la muestra final se conoce cuando las nuevas unidades ya no aportan información o datos novedosos, aún cuando se agregan casos extremos (Hernández et al., 2014), de modo que se buscó comprender a profundidad la experiencia de un pequeño grupo de personas, mas no la generalización de toda la población.

En base a ello, se contó con 7 madres y 5 padres. La edad del grupo abarcó un rango entre 20 y 48 años, siendo la edad promedio 32 años. En relación con el lugar de procedencia, se distingue una clara mayoría de los padres que provienen de la Costa (6) y la Selva (5) en relación a los que provienen de la Sierra (1). La muestra es predominantemente católica (7).

Respecto al nivel de instrucción, más de la mitad de los entrevistados ha concluido con los estudios secundarios. La cuarta parte tiene estudios incompletos de secundaria y los que cuentan con un nivel inferior (primaria completa) fueron únicamente dos.

Tabla 4.1.

Variables Sociodemográficas (1)

\begin{tabular}{ccccc}
\hline Edad & Sexo & Lugar de procedencia & Grado de instrucción & Religión \\
\hline 20 & F & Ucayali & Secundaria completa & Ninguna \\
28 & M & San Martín & Secundaria completa & Católica \\
40 & F & Chiclayo & Secundaria completa & Cristiana \\
33 & M & Iquitos & Secundaria incompleta & Cristiano \\
27 & F & San Martín & Primaria completa & Católica \\
32 & M & Tacna & Secundaria completa & Católica \\
35 & F & Piura & Secundaria completa & Católica \\
38 & M & Piura & Secundaria completa & Católica \\
31 & M & Lima & Secundaria incompleta & Ninguna \\
48 & F & Lima & Secundaria completa & Católica \\
31 & F & Cajamarca & Secundaria incompleta & Católica \\
25 & F & Ucayali & Primaria completa & Evangélica \\
\hline
\end{tabular}


La mayoría de las madres (4) se dedica al cuidado del hogar y de sus hijos. El resto de ellas se distribuye entre las diversas ocupaciones. Los padres realizan actividades independientes, ya sea de agricultura, pesca o servicio de taxis. Ninguno ejerce una profesión relacionada a estudios superiores.

En cuanto al nivel socioeconómico de las familias -según los criterios del Departamento de Servicio Social del Instituto de Enfermedades Neoplásicas-, la gran mayoría (10), corresponde a un nivel de pobreza crónica, mientras que el resto es indigente (pobreza extrema). Cabe mencionar que la clasificación de pobreza extrema y crónica fue realizada por el Servicio Social de la institución, en base a los estándares propuestos por el Seguro Integral de Salud (INEN, 2015b).

Tabla 4.2.

Variables Sociodemográficas (2)

\begin{tabular}{|c|c|}
\hline NSE & Seguro afiliado \\
\hline Pobreza crónica & SIS gratuito \\
\hline Pobreza crónica & SIS gratuito \\
\hline Pobreza crónica & SIS gratuito \\
\hline Pobreza crónica & SIS gratuito \\
\hline Pobreza crónica & SIS gratuito \\
\hline Pobreza crónica & SIS gratuito \\
\hline Extrema pobreza & SIS gratuito \\
\hline Extrema pobreza & SIS gratuito \\
\hline Pobreza crónica & SIS gratuito \\
Pobreza crónica & SIS gratuito \\
Pobreza crónica & SIS gratuito \\
Pobreza crónica & SIS gratuito \\
\hline
\end{tabular}

\subsection{Técnicas de recolección de información}

Se realizaron entrevistas a profundidad semi-estructuradas para explorar las representaciones sobre la leucemia, las cuales estuvieron basadas en guías elaboradas por Ruda (2001), Moldovan (2009) y Ladino (2011), y en los componentes de las representaciones del cáncer considerados por Leventhal et al. (1980), que giran en torno a cinco dimensiones (identidad, causas, 
consecuencias, línea de tiempo y cura/ control de la enfermedad). No obstante, dada la necesidad para precisar conceptos y obtener mayor información sobre los temas deseados, una nueva guía de preguntas fue creada y revisada en compañía de un experto en la materia (Anexo 1), la cual tras un trabajo de inmersión de campo que se realizó con dos sujetos, que no formaron parte de la muestra, pero que cumplieron con los criterios de inclusión, quedó definida. Finalmente, a partir de los resultados obtenidos, se formaron categorías de análisis.

Este método de recolección de información resulta el más adecuado para medir este constructo, pues revela el significado de las experiencias de las personas en base a lo vivido y brinda posibilidades de comprensión desde la perspectiva del actor (Kvale, 2008). Además, le permite al entrevistador introducir algunas preguntas adicionales en el caso se requiera (Hernández et al., 2010).

\subsection{Procedimiento de recolección de datos}

Se inició con el envío de la solicitud a la institución para poder llevar a cabo la investigación, la cual fue revisada por el Departamento de Investigación y el Comité de Ética de la misma. Cuando se tuvieron los permisos necesarios, se procedió a realizar una inmersión de campo, para así validar la guía de preguntas. Esta se realizó con dos padres que cumplieron con los criterios señalados anteriormente. Al finalizar, se procedió a revisar las historias clínicas y a seleccionar aquellas que cumplían con criterios para el estudio. Para ello, se llenó una ficha con información acerca de las variables de la enfermedad.

Posteriormente, se realizó el acercamiento a los padres, se les explicó el objetivo de la investigación y se les invitó a la sala de reuniones del Servicio de Pediatría con la finalidad de que participen del estudio. Una vez ahí, se les entregó el consentimiento informado (Anexo 2), así como la ficha sociodemográfica, para luego proceder a explicarles con mayor detalle la finalidad del estudio. Al finalizar, se siguió con las entrevistas de manera individual. 


\subsection{Estrategias de análisis de datos}

Primero, se inició con transcribir las narrativas de las experiencias y agregar la información que se haya recogido de la base de datos. Luego, se procedió a revisar todas las descripciones e información para tener un panorama completo. Seguido a ello, se pasó a identificar las unidades de análisis, para luego generar categorías, a fin de encontrar códigos patrón en las descripciones y narrativas. Después, se procedió a descubrir la conexión entre las experiencias de los participantes y las variables sociodemográficas planteadas con anterioridad. Finalmente, se desarrolló una narrativa general que incluye las categorías y los temas comunes y heterogéneos, presentados individualmente, así como sus vínculos dentro del contexto, siendo el producto final una descripción de la experiencia común y de las categorías emanadas a partir de las experiencias (Hernández et al., 2014). 


\section{CAPÍTULO V: RESULTADOS}

\section{Tema 1: Identidad}

Respecto al tema de identidad, éste será descrito en base a cuatro categorías: la conceptualización, la recepción de la información, la explicación previa de la enfermedad y los conocimientos previos.

\section{Categoría 1.1. Conceptualización}

En relación a la primera categoría, los padres aludieron al concepto de la misma como células cancerígenas, células malas, sangre sucia, virus, manchas negras y un animalito.

En relación a las células cancerígenas, hicieron referencia a las mismas al mencionar que son blastos, ubicados en la sangre que generan la pérdida de consistencia de la misma, dado el ataque hacia el resto de células.

"La leucemia es un cáncer a la sangre (...) Hay personas que tienen blastos que son células cancerígenas que están en la sangre y eso nada más."

(E3): Mujer, Lambayeque, secundaria completa, pobreza crónica.

"Es una enfermedad que ataca la sangre. Es unas células cancericias que tiene la sangre y que tienen que eliminarlas para que la bebe esté bien."

(E2): Hombre, San Martín, secundaria completa, pobreza crónica.

\section{“(...) un cáncer en la sangre que tiene un proceso largo y que puede} recaer (...) que todo lo que está en las células buenas, le produce agua y se va cayendo y se va atacando todo lo que es en la sangre más que todo (...) las células malas que están a las células buenas van atacando." (E6): Hombre, Tacna, secundaria completa, pobreza crónica.

Otra representación también fue plasmada al otorgarle el carácter de sangre sucia, lo cual puede verse como el producto del ataque y la invasión de células, y va ligado a la idea de contaminación. 
“Eso nomás. Leucemia: cáncer a la sangre. Nada más (...) algo como si su sangre está medio sucio, una bacteria." (E4): Hombre, Iquitos, secundaria incompleta, pobreza crónica.

Con respecto al virus, se evidenció la necesidad de aludir la presencia de un elemento externo, mas no interno que ingresa al organismo de manera invasiva, destruyéndolo. En esta conceptualización, junto a la de células cancerígenas y células malas, se percibió una sensación de pérdida de control, al hablar acerca de su aparición e invasión por todo el organismo.

"La leucemia es un virus que ataca su cuerpo (....) Destruye la sangre, todo lo bueno que tiene en su sangre." (E1): Mujer, Ucayali, secundaria completa, pobreza crónica.

En relación a las manchas negras, vincularon su aparición con la enfermedad, viéndose la necesidad de buscar un elemento visible que la represente, dado que la leucemia carece de una tumoración sólida.

\section{“(...) yo no sabía qué era esa enfermedad (...) Decía que era a la} sangre. Yo pensaba que la leucemia era por las manchitas negras. Pero dicen que en la sangre está (...) Cuando me dijeron que tenía leucemia yo pensaba que era por las manchitas negras. Por eso es que no entiendo yo. Porque al decirme que esas manchitas negras eran las plaquetas, no entiendo hasta ahorita." (E5): Mujer, San Martín, primaria completa, pobreza crónica.

En relación al animalito, se ilustró la necesidad de imaginarlo como un ser vivo que devora y destruye el organismo, a fin de concretizar la enfermedad.

“(...) es un virus que se ha metido a la sangre (...) que no avisa (...) que se mete entre los huesos, al medio en la sangre que corre (...) donde están los glóbulos rojos y los está matando. Que ese animalito, ese virus sale y hace que los glóbulos rojos se los coma, no produce los glóbulos rojos." (E8): Hombre,

Piura, secundaria completa, extrema pobreza (indigente).

Cabe mencionar que el carácter destructivo de la enfermedad, generado por el propio organismo, estuvo más presente a medida que aumentó el nivel de instrucción de los padres, dado que a menor nivel de instrucción se evidenció la necesidad de representarla mediante un agente externo que ingresa al organismo y lo destruye. De igual modo, en padres con menor nivel de instrucción, se vio una mayor necesidad de visualizar la enfermedad, mediante una señal externa, como puede ser una mancha. 


\section{Categoría 1.2. Recepción de la información}

En relación a la segunda categoría, se encontró que los padres recibieron la información acerca de la leucemia por parte del personal de salud, padres de niños hospitalizados, personas de su entorno, medios de comunicación y curanderos.

Aludieron que, antes de saber que su hijo tenía el diagnóstico de leucemia, buscaron una explicación al conjunto de síntomas por medio de otras personas, los medios de comunicación y del personal asistencial de sus centros de salud.

Refirieron haber pedido opiniones a personas de su entorno, a fin de que les brinden una posible explicación acerca del conjunto de síntomas que experimentaban sus hijos, además de algunas ideas de cómo tratarlos, ya sea en base a su experiencia y/o conocimientos cotidianos.

“(...) en la calle preguntaba de qué proviene pero nadie me decía de qué proviene (...) a fin de cuentas pregunté acá, busqué gente mayor que me

dijera. Le di algunos datos de cómo está la bebe y me dijeron que era leucemia." (E2): Hombre, San Martín, secundaria completa, pobreza crónica.

También, aludieron guiarse de los medios de comunicación (programas de televisión, periódico, internet y libros) y de la información que estos proporcionaban.

"Y después de eso, entré al sistema, a la computadora porque trataba de explicarme lo que tenía, pero salía leucemia (...) Y cuando llego a mi casa, le digo a mi mamá, "tiene células inmaduras", entré a la computadora y me salió eso: leucemia.” (E10): Mujer, Lima, secundaria completa, pobreza crónica.

“En películas, en la tele, en las noticias, en el periódico. En el colegio con los libros también." (E9). Hombre, Lima, secundaria incompleta, pobreza crónica.

De igual modo, padres provenientes de la Selva mencionaron que supieron de la existencia de la enfermedad a través de los curanderos de su pueblo.

"Por un curandero que vende así remedios naturales escuché (...) así hablaba por las emisoras, por la radio.” (E5). Mujer, San Martín, primaria completa, pobreza crónica. 
No obstante, refirieron que fue por medio del personal de salud como realmente recogieron la mayor cantidad de información sobre la leucemia, sobre su tipología, desarrollo, gravedad y tratamiento tras la confirmación del diagnóstico de sus hijos. Aludieron que ello se llevó a cabo por medio de las conversaciones con los médicos y enfermeros en el Servicio de Emergencias del hospital y luego cuando subieron al Servicio de Pediatría.

“Aquí, en el hospital (...) Lo aprendí desde que mi hija está enferma. De ninguna parte más (...) cuando llegué a emergencia, ahí la doctora me explicó cómo es el virus. Que ella tiene leucemia y que esto es así, que tiene etapas y si no se controla, este se puede morir si es que no lo controla. De ahí acá tuvimos una charla de padres para este saber un poquito que la leucemia tiene dos tipos de leucemia que es la LLA y la leucemia mieloide que es la más agresiva."

(E1): Mujer, Ucayali, secundaria completa, pobreza crónica.

De igual modo, afirmaron que también adquirieron parte de la información por parte de otros padres de niños hospitalizados y que juntos buscaron indagar el significado de ciertos términos médicos que no comprendían, así como acerca del tratamiento de quimioterapia y de su efectividad, siendo esta cuestionada en varias ocasiones tras escuchar experiencias de recaída en otros pacientes. En este caso, las mujeres fueron quienes más se guiaron de este recurso.

"Aquí recién lo he venido a aprender, yo ni en sueños (...) aquí me pregunto mediante las madres, aunque los doctores también me dijeron, pero ellos me dicen esos términos que yo trato de averiguar por madres (...) o las de abajo que también vienen a la quimioterapia ambulatoria." (E7): Mujer, Piura, secundaria completa, pobreza extrema (indigente)

\section{Categoría 1.3. Explicación previa de la enfermedad}

En cuanto a las explicaciones previas de la enfermedad, los padres mencionaron que antes de recibir el diagnóstico, creían que se trataba de una infección, del síndrome de púrpura de la sangre, de una anemia, un golpe y del susto, considerándose este último un factor cultural.

Al mencionar la infección, los padres refirieron como principal agente la gripe, la fiebre y el mal intestinal, aludiendo que estas fueron experimentadas 
previamente por sus hijos o por personas de su entorno. No obstante, ante la persistencia y/o incremento de síntomas, se vieron en la necesidad de acudir a un centro de salud cercano en busca de una explicación y un tratamiento.

“(...) pensaba que era una fiebre, normal. Pero hasta que yo mismo me di cuenta que se empezó a poner flaquita, estaba pálida, la vi pálida, amarilla, los ojos hundidos, todo. Hasta que ya acudí al doctor. Yo no me imaginé ahí que era leucemia, pensé que era una infección al estómago. $Y$ de ahí me dijeron "está baja de sangre”, “ah, seguro la alimentación, pensé”. No me imaginaba leucemia.” (E8): Hombre, Piura, secundaria completa, extrema pobreza (indigente)

Asimismo, los padres refirieron el síndrome de púrpura de la sangre, como explicación previa ante el conjunto de síntomas experimentados, siendo esta contraída anteriormente. Ello se vincula nuevamente a la idea de que los padres suelen creer que se trata de una enfermedad previamente experimentada, más aún si guarda similitud respecto a su sintomatología.

“(...) allá en Chiclayo ...el doctor me dijo qué era... que su diagnóstico era un síndrome de purpura de la sangre que es una enfermedad también en la sangre." (E3): Mujer, Lambayeque, secundaria completa, pobreza crónica.

Por otro lado, la anemia también fue una explicación común dada por los padres, previo al conocimiento del diagnóstico, dada la semejanza en los síntomas experimentados, pues ambas se vinculan a la condición sanguínea.

"Una anemia, pero una anemia muy mal (...) por mala alimentación, por higiene (...) nosotros lo veíamos pálido. Parecía que tenía anemia. Estaba un poquito amarillo también." (E6): Hombre, Tacna, secundaria completa, pobreza crónica.

Un golpe también fue aludido como explicación previa, al estar relacionado con la dificultad para andar, lo cual, ligado a la debilidad física, es un síntoma que se asemeja al de la leucemia.

“(...) de repente le empezó a doler el pie (...) Porque cuando estaba jugando partido se dobló (...) se golpeó. Puede ser por una fractura, una lesión, algo.” (E9): Hombre, Lima, secundaria incompleta, pobreza crónica.

También refirieron explicaciones de índole cultural como el susto y el espanto, los cuales guardaron relación con las creencias de su lugar de procedencia. 
“O sea allá decían que podía ser el susto, el espanto (...) Que cuando a veces se caen en un sitio malo (...) O sea mi hijita se cayó una vez de un puente al agua. Y decían que ella se ha espantado ahí.” (E5): Mujer, San Martín, primaria completa, pobreza crónica.

\section{Categoría 1.4. Conocimientos previos}

En cuanto a la conceptualización de la leucemia, se evidenció la falta de conocimiento previo acerca de lo que trata esta enfermedad. No obstante, gran parte de los entrevistados refirió haber escuchado anteriormente acerca de la anemia y el cáncer, viéndose este último como una enfermedad grave que puede conducir a la muerte, dado que no solo implica un deterioro en la sangre. Ello fue evidente en padres con un mayor nivel de instrucción.

“No, nada. Sabía que era lo otro ¿cómo se llama? (...) Anemia, eso.

Pero de leucemia no." (E12): Mujer, Ucayali, primaria completa, pobreza crónica.

"Bueno, anteriormente, para mí era un sintoma de muerte." (E4):

hombre, Iquitos, secundaria incompleta, pobreza crónica.

“(...) había escuchado pero no tanto nomás. Solo leucemia: cáncer a la sangre.” (E1): mujer, Ucayali, secundaria completa, pobreza crónica.

Asimismo, aludieron que antes de saber que su hijo tuviera leucemia, no conocían el origen de la misma.

“No sé, hasta ahora no sé de qué previene." (E11): Mujer Cajamarca, secundaria incompleta, pobreza crónica

En cuanto al tratamiento, los padres mencionaron que antes de conocer el diagnóstico de sus hijos desconocían el tratamiento que ofrecía la medicina convencional. Padres con menor nivel de instrucción y provenientes de la Selva mencionaron que no conocían la medicina convencional, pues solían utilizar medicina natural y acudir a curanderos del pueblo, en lugar de centros médicos. Pensaban que se trataba con plantas naturales y cortezas de palos, dado que desconocían la quimioterapia. Incluso, aludieron que presentaban dudas con respecto a la posibilidad de cura con la medicina convencional, puesto que habían escuchado en sus lugares de procedencia que los curanderos curaban de por vida y los médicos por temporadas. 
“(...) un tratamiento muy largo (...) yo más bien escuchaba leucemia y pensaba que lo cambiaban su sangre (...) yo no sabía qué era quimio tampoco (...) pensé que eran ampollas así, ahora si poco a poco si estoy sabiendo que le ponen a la vena así.” (E3): Mujer, Lambayeque, secundaria completa, pobreza crónica.

"Decía que si el doctor dice que tiene leucemia, él le cura con plantas naturales. Pero yo ese rato cuando dijeron que tenía leucemia no me acordaba de ese señor. Dice que él cura porque los doctores solo curan por temporadas y que él lo cura para toda la vida, con plantas, con cortezas de palos dice que cura. Acá me he acordado que de leucemia hablaba ese señor." (E5): Mujer,

San Martín, primaria completa, pobreza crónica.

En cuanto a la gravedad, quienes habían escuchado de la leucemia y del cáncer en general, refirieron que sabían que se trataba de una enfermedad muy peligrosa.

“(...) me habian explicado que la leucemia era una enfermedad muy peligrosa (...) que el cáncer en sí no se curaba, pero nunca me imaginé que era la leucemia (...)” (E2): Hombre, San Martín, secundaria completa, pobreza crónica.

Asimismo, en cuanto a la posibilidad de cura, aludieron que quienes habían escuchado acerca de ella y del cáncer en general, creían que ello no era posible.

“Cuando me dijeron cáncer, uy no, mi hijita estará un mes, dos meses y de ahí se me va. Esa es mi verdad que pensé. Pero me han ido explicado poco a poco que hay cura y me ido calmando." (E8): Hombre, Piura, secundaria completa, extrema pobreza (indigente)

\section{Tema 2: Causas}

En relación al tema de causas, este será descrito en base a ocho categorías: biológico, medio ambiente, sanitarias, alimentación, dinámica familiar, golpe, místico-religioso y azar. 


\section{Categoría 2.1. Biológico}

En relación a la causalidad de tipo biológico, los padres refirieron el desorden intracelular, la anemia, la vida intrauterina y la herencia, como los principales factores.

En cuanto al desorden intracelular, se evidenció la necesidad de visualizar estas células como un conjunto de elementos que se instaura e invade el cuerpo de manera descontrolada y desorganizada, generando daño interno. Esta representación fue dada por padres con un mayor nivel de instrucción.

“(...) por el desorden de las células (...) Y es que en estos niños que no hayan tenido ningún familiar que lo haya tenido es por un desorden de las células (...) solo que estas células estuvieran como loquitos y crean más células (...) estas células malas se crean en exceso. Son células malignas que se van regando en todo el cuerpo." (E1): Mujer, Ucayali, secundaria completa, pobreza crónica.

La anemia también fue referida como un factor influyente, al asociarla con el tipo de alimentación brindado y con la inhalación de productos tóxicos.

"Por la anemia que lo agarró primero porque a ella le gustaba funegar, porque lo olía a los remedios se acercaba, a la gasolina también se acercaba a oler. Creo que por eso le dio la anemia, le bajaron sus defensas y le dio esa enfermedad." (E5): Mujer, San Martín, primaria completa, pobreza crónica.

La vida intrauterina también fue aludida como un factor importante, siendo los estados emocionales experimentados por la madre lo influyente en el desarrollo del niño.

“(...) he pensado que es de una tristeza profunda del niño que he llevado yo del embarazo (...)” (E10): Mujer, Lima, secundaria completa, pobreza crónica.

El factor hereditario también estuvo presente en su representación, al aludir que la presencia de algún miembro de la familia puede influir en su aparición.

“(...) y también que tan solo alguien en la familia lo haya tenido, para que lo haya heredado (...) o sea si alguien en tu familia, como el abuelo, ha 
tenido, recién puede ser." (E1): Mujer, Ucayali, secundaria completa, pobreza crónica.

\section{Categoría 2.2. Medio ambiente}

En cuanto al medio ambiente, el clima y la contaminación, estos fueron nombrados como factores contribuyentes al desarrollo de esta enfermedad.

En relación al clima, los padres mencionaron los cambios bruscos de temperatura como los agentes causantes. Aludieron ser estos de carácter externo e incontrolable.

“(...) a veces tengo una idea que puede ser calor, pero ¿en qué forma? Puede ser que a la bebe no le hace el clima (...)” (E2): Hombre, San Martín, secundaria completa, pobreza crónica.

Asimismo, se evidenció la idea de que esta enfermedad suele derivarse de la inmersión en ambientes contaminantes y del contacto con productos y sustancias tóxicas que se encuentran en casa, siendo los pesticidas los más referidos. El impacto negativo de la exposición de la tecnología también fue mencionada.

“(...) se me ocurre, digo que de repente yo trabajo allá a la chacra con enticidas, pesticidas o con herbicidas y la bebe para conmigo. Es una bebe que siempre para detrás de la mí, al lado de la mochila, hasta incluso me hace el servicio de pasarme los remedios (...) Minería no hay cerca donde vivimos porque a veces he preguntado y minería no hay. Hay más lejos" (E2): Hombre,

San Martín, secundaria completa, pobreza crónica.

“(...) dicen que cuando uno en la casa tiene por ejemplo productos de insecticidas, así industriales puede ser un factor." (E3): Mujer, Lambayeque, secundaria completa, pobreza crónica.

"A veces estaba encerrado, mucha computadora, mucho cable, mucho televisor (...) El exceso de tecnología, bueno cada aparto electrónico genera rayos de magnesio, también puede ser eso ¿no? (...) Me imagino también puede ser por eso.” (E9): Hombre, Lima, secundaria incompleta, pobreza crónica. 


\section{Categoría 2.3. Condiciones sanitarias}

En cuanto a las condiciones sanitarias, los padres aludieron la limpieza, las sustancias y la falta de acceso al servicio sanitario como los causantes de la enfermedad.

En relación a la limpieza, mencionaron la influencia de la falta de hábitos de limpieza de la vida diaria, del aseo personal, así como la falta de desinfección de productos que se ingieren como factores causales. Así como la presencia de animales en casa. A mayor nivel de instrucción se evidenció mayor conciencia en cuanto a la práctica de hábitos de higiene personal.

“También digo yo medio ambiente ¿no? Por el gato, el perro. A mi hijita le gustaba agarrarle el gato, yo le decía “deja de agarrar el gato”, pero ella le agarraba, le abrazaba, su naricita respirando. Yo digo de repente por ese gato le ha dado, porque no es bueno que la bebe le estuvo abrazando al gato." (E4):

Hombre, Iquitos, secundaria incompleta, pobreza crónica.

"La higiene que tenemos cada uno también (...) El aseo de cada uno, al terminar de comer, al lavarse las manos." (E8): Hombre, Piura, secundaria completa, extrema pobreza (indigente)

En cuanto a las sustancias en sí, los padres refirieron la influencia negativa de medicinas otorgadas por el personal de centros de salud, dado el uso y abuso de las mismas. Ello fue predominantemente aludido en padres con un mayor nivel de instrucción.

“(...) y yo digo también que cuando recaía con gripes, siempre me mandaban "Amoxicilina" y yo cuando mi hija la mandaba al pediatra me decían que no, que mi hija tenía talla de un adulto y un peso de un adulto, que

ella no era de jarabes, sino de pastillas. Y cuando ya la llevé acá a la Solidaridad que le detectaron, ellos dijeron "qué burros son los doctores de Paita, se supone que es una niña, si ella tiene el peso y la talla de un adulto, ella sigue siendo niña, porque sus órganos siguen siendo de una niña”. Y ellos me mandaron jarabes. Y entonces yo me pongo a pensar que todo este factor de medicinas también han quemado glóbulos (...) Ahí yo digo que en provincia hay parte de negligencia... muy fuerte esas medicinas." (E7): Mujer, Piura, secundaria completa, pobreza extrema (indigente) 
“Vacunas no, pero sí puede ser el uso y el abuso de los antibióticos que uno le daba para la gargantita. Y eso constantemente puede haber deprimido el sistema inmunológico o puede haber creado un desbalance de los componentes de la sangre.” (E10): Mujer, Lima, secundaria completa, pobreza crónica.

Asimismo, se evidenció un desconocimiento acerca de la importancia de someter a sus hijos a análisis y controles médicos previos a lo largo de su desarrollo, lo cual puede relacionarse con la falta de información acerca de la importancia de la prevención de enfermedades y promoción de la salud en los diferentes sectores, no encontrándose diferencias según género, nivel de instrucción ni lugar de procedencia.

"Puede ser también porque después de los dos años ya no le llevé a sus controles de la posta. Por eso no le han pusido las vacunas después de los 2."

(E5): Mujer, San Martín, primaria completa, pobreza crónica.

“(...) de repente a la bebe no le sacamos una placa o una radiografía o algún análisis de pequeña porque no caía enferma." (E2): Hombre, San Martín, secundaria completa, pobreza crónica.

\section{Categoría 2.4. Alimentación}

Padres aludieron a la alimentación, como otro factor desencadenante de la leucemia. Refirieron como principal factor la discontinuidad en la ingesta de leche, lo cual guarda relación con la lactancia materna, y ello a su vez con la relación materno-fílial.

“(...) lo que yo tengo entendido es que la leucemia viene de que es un virus que se le mete a cualquiera y viene que no nos alimentamos bien. Por ejemplo en el caso de mi hija nunca tomó leche de chiquita, nunca, para qué soy bien sincero. Mi hijita tomaba té, café y nunca leche y las señoras me decían “dale leche que después va a sufrir" y yo le decía a mi mujer "mira hija, no tomó leche, no tomó sopa, ahí están las consecuencias, no se ha producido más sangre, ahí está la leucemia. Por eso flaquita ha venido” (...) En el caso de Grecia yo creo le dio por la alimentación, debo ser franco. En mi mente está el no haber tomado la leche, sopa. De eso ha sido, no ha tenido fuerzas, ningún protector que la proteja. Porque ella ha sido puro te-café-sopa. Y eso ha sido 
el problema, la alimentación." (E8): Hombre, Piura, secundaria completa, pobreza extrema (indigente)

“(...) ella no me comía leche, pero yo le suplantaba con el puré, el ají de pollo, en el fresa con leche que era yogurt. Pero eso sí, mi hija siempre ha sido exquisita para comer las verduras en la sopa, solamente se comía el líquido y unos cuantos fideos. Y ahora aqui yo le digo "ya ves, por no comer, yo qué te

dije, por eso te pasa” (E7): Mujer, Piura, secundaria completa, pobreza extrema (indigente)

En cuanto al nivel de instrucción, se encontró que a mayor nivel hay un conocimiento más complejo sobre los hábitos alimenticios saludables y también sobre la existencia de nutrientes que benefician al organismo.

"Dicen que cuando no le das la menestra. Ella no le comía la menestra. Ella comía su arroz, su plátano, su huevito. Su carne, de primero también lo comía. Yo le mataba a mis gallinas, eso comía. Después ya no, y hasta ahorita ya no quiere comer.” (E5): Mujer, San Martín, primaria completa, pobreza crónica.

"Mayormente una explicación que me da a cabeza es que el aceite es perjudicial y el cuerpo no asimila bien los nutrientes y ahí se va formando un desbalance que va siendo intrusivo." (E10): Mujer, Lima, secundaria completa, pobreza crónica.

En cuanto al lugar de procedencia, se ilustró una mayor preocupación en relación a la lactancia materna en madres de la Sierra, a diferencia de las de la Costa y la Selva.

"Ella no toma leche, dejó de lactar al año, 5 meses. No le gusta la leche. Acá toma el pediasure pero poquito (...) Tengo miedo que a mi hijo también le pase eso porque él come poco también. Comen frituras. Carne de res era todos los dias cuando es una vez por semana." (E11): Mujer Cajamarca, secundaria incompleta, pobreza crónica.

\section{Categoría 2.5. Dinámica familiar}

Esta categoría incluye los conflictos de la dinámica conyugal y la sobreprotección, como factores determinantes, nombrados por los padres. 
En cuanto a los conflictos de la dinámica conyugal, los padres mencionaron que ello pudo haber impactado en sus hijos a nivel emocional y consecuentemente en su sistema inmunológico, pudiendo así ser un factor contribuyente al desarrollo de la enfermedad.

"Yo sentía eso, cuando me peleaba con ella. Yo digo que eso absorbía mi hijita." (E4): Hombre, Iquitos, secundaria incompleta, pobreza crónica.

"El niño ha sido como una esponja, como si él hubiera absorbido todo, por ejemplo lo de mi anterior pareja que le conté ha sido muy negativo, como si hubiera absorbido todo eso. Las tristezas y las peleas también. Porque su padre es un hombre seco, no muy cariñoso." (E10): Mujer, Lima, secundaria completa, pobreza crónica.

Por otro lado, la sobreprotección también fue un tema que figuró como factor causal, al señalar que el exceso de cuidado puede haberles privado de la posibilidad de desarrollar anticuerpos ante la presencia de enfermedades e infecciones.

"Me dice mi cuñada "tú no la criaste a los anticuerpos, siempre la tuviste como una muñequita, que quieres que se ensucie”. Y me llegaban a veces amiguitos, su papá también tuvo parte culpa. Este no ahorita no, está que ve tele, su papá le compraba cuentos de princesa para que lea que a ella le gusta leer, o sino ver cuentos de princesa, se ponía a ver. Si venían sus amiguitas se ponían a ver. Compartían ahí alguna cosa con ella. Pero si su papá venía y veía que estaban jugando a las escondidas o a la pelota, uy no, estaba que decía está que se suda la bebe, que la ropa bonita. Y eso no ha sido bien tampoco." (E7):

Mujer, Piura, secundaria completa, pobreza extrema (indigente)

\section{Categoría 2.6. Golpe}

Los padres también vincularon la aparición de la leucemia con una caída, lo cual refleja la necesidad de buscar la explicación hasta en las situaciones más cotidianas, teniendo en cuenta que este también produce moretones, lo cual es parte de la sintomatología de la leucemia.

"Un golpe puede ser, porque la bebe es una bebe inquieta. Paraba colgada de los palos. No ha tenido alguna rotura por una caída, pero siempre 
se ha caído la bebe pero nada. Le hubiese causado a la médula, pero si la médula marcha bien, no sé." (E2): Hombre, San Martín, secundaria completa, pobreza crónica.

\section{Categoría 2.7. Místico-Religioso}

En cuanto a esta categoría, los padres también hicieron alusión a lo místico, al hablar del destino. Aquellos que eran creyentes, hicieron referencia a que era una prueba y/o castigo de Dios, siendo este último asociado a la presencia de conflictos a nivel de la dinámica conyugal.

"No sé por qué le puede haber dado o porque es cosa del destino que le haya dado (...) Porque así habrá tenido que ser su futuro de ella. O sea... porque no puedo pensar otra cosa le puede haber dado." (E1): Mujer, Ucayali, secundaria completa, pobreza crónica.

“(...) yo creo que es una prueba de Dios, es lo que pienso yo. Que es una prueba de Dios, que Dios sabe por qué le ha dado esa enfermedad a mí. No sé, yo creo que es una prueba que Dios me ha mandado para que, bueno para estar en más comunión con él." (E3): Mujer, Lambayeque, secundaria completa, pobreza crónica.

"O también me he puesto a pensar cuando de repente nosotros nos hemos portado mal, los papás se han peleado, Dios tiende a castigarlos también mediante los niños. Que a los niños les haya caído eso (...) Que por ejemplo yo y mi esposa me separé, los dos sufrimos. Es como un castigo." (E6): Hombre,

Tacna, secundaria completa, pobreza crónica.

\section{Categoría 2.8. Azar}

En cuanto al azar, los padres refirieron que esta enfermedad se presenta sin ningún motivo en especial, viéndola como algo incontrolable en lo que se refiere a su aparición.

"Mmm ... también tengo entendido que por los mil niños que nacen, a uno le puede dar (...) Que de los mil a uno de los niños." (E4): Hombre, Iquitos, secundaria incompleta, pobreza crónica. 


\section{Tema 3: Consecuencias}

En relación a las consecuencias, éstas serán descritas en base a cuatro categorías: a nivel físico, cognitivo, emocional y conductual.

\section{Categoría 3.1. A nivel físico}

En relación al género, las madres fueron quienes establecieron mayor relación entre el estado físico actual de sus hijos y el tratamiento, al referir que este suele ser efecto del mismo, lo cual puede relacionarse con el hecho de que suelen ser ellas quienes generalmente acompañan a sus hijos durante todo el periodo de hospitalización.

“(...) sus defensas están bajos (...) Ahorita está respondiendo bien, sino que las quimioterapias hace que le salga heridas en la boca, o que tenga fiebre, pero difícil que presente esto. Solo está presentando dos veces fiebre y no tiene otro tipo además de síntomas (...) También tiene sus pies fríos. Y bueno ahorita está que engorda, porque cuando llegó estaba flaquita (...) está más gordita de

lo que había llegado, más cachetoncita." (E1): Mujer, Ucayali, secundaria completa, pobreza crónica.

En cuanto al nivel de instrucción, no se evidenciaron diferencias en relación a los cambios físicos que experimentaron sus hijos, una vez iniciado el tratamiento de quimioterapia. Estos estaban asociados con la caída de cabello, los cambios en el apetito y, consecuentemente, en el peso. Y también con el malestar físico, así como con la disminución de fuerza física. Reconocieron que ello dependía en gran medida del estado actual de su organismo, dada la enfermedad, siendo el nivel de sus defensas lo más referido.

“Ahorita está respondiendo bien, a veces baja sus plaquetas, pero una vez nomás le han puesto sus plaquetas concentradas, hemoglobina, pero vuelta sube, asi." (E3): Mujer, Lambayeque, secundaria completa, pobreza crónica.

“(...) no quiere comer también, eso es lo que me preocupa. Por las quimioterapias. Sí porque ya estuvo comiendo, la semana pasada no comía tampoco. El miércoles pasado estaba comiendo y le salieron granitos, pero de ahí el jueves le pusieron la quimio y vuelta ya no quiere comer (...) Ella no quiere estar echada, no quiere estar en su cama. Por momentitos la echo en su 
cama. Ella quiere estar caminando." (E5): Mujer, San Martín, primaria completa, pobreza crónica.

No obstante, cuando se trató de la proyección a mediano y largo plazo, los padres con mayor nivel de instrucción pudieron hacerlo sin dificultad, evidenciando mayor conciencia acerca del impacto de la enfermedad oncológica y el tratamiento, siendo capaces de establecer relaciones entre ellos. Padres con menor nivel de instrucción mencionaron creer que una vez acabada la primera hospitalización, sus hijos volverían a lucir y funcionar internamente como antes, sin repercusiones negativas en su desarrollo.

"Más recia que esté (...)” (E5): Mujer, San Martín, primaria completa, pobreza crónica.

“(...) he escuchado comentarios no podría tener normal cuando ya sea grande sus hijos, y bueno eso no quisiera que le afecte (...) Bueno como es cáncer a la sangre, tengo miedo que le afecte en sus partes (...)” (E4):

Hombre, Iquitos secundaria incompleta, pobreza crónica.

“Le puede afectar en su tamaño y su crecimiento (...) de repente puede quedar algo especial o no (...) quedar inválida por mucha quimio por mucha química (...) Ojalá que no le tenga problemas.” (E2): Hombre, San Martín, secundaria completa, pobreza crónica.

Los padres con mayor nivel de instrucción también hicieron alusión a experiencias de otros niños. Si bien mencionaron confiar en el tratamiento, también aludieron tener suspicacia, al temer a que los químicos afecten en su crecimiento y desarrollo en general, pudiendo así quedar inválidos y con dificultades para concebir. De igual modo, mencionaron temer a que sus defensas se mantengan bajas y a que la enfermedad progrese, dada su condición de gravedad.

“(...) yo veo a niñitas cómo salen de acá, como unas viejitas, bien flaquitas salen. Eso me pongo a pensar así.” (E7): Mujer, Piura, secundaria completa, pobreza extrema (indigente)

"Le puede afectar en su tamaño y su crecimiento (...) de repente puede quedar algo especial o no (...) quedar inválida por mucha quimio por mucha química (...) Ojalá que no le tenga problemas. $O$ de repente el problema de que le rebrote la enfermedad en unos años" (E2): Hombre, San Martín, secundaria completa, pobreza crónica. 
“(...) ahorita sus plaquetas están bien, pero con esta enfermedad siempre hay que tenerlo monitoreado y saber su promedio de plaquetas, de hemoglobina (...)” (E10): Mujer, Lima, secundaria completa, pobreza crónica.

\section{Categoría 3.2. A nivel cognitivo}

Los padres manifestaron preocupación en relación a la pérdida del año escolar, dada la necesidad de hospitalización continua para recibir el tratamiento. Mencionaron temer que a mediano y largo plazo sus hijos pierdan su potencial y les sea difícil nivelarse en sus estudios y sobresalir, dada las posibles secuelas del tratamiento y el probable deterioro causado por la enfermedad, lo cual fue aludido en padres con un mayor nivel de instrucción.

"Yo que decía que mi hija tenía potencial, me dediqué a ella a enseñarle a que ella va a ser la mejor. Siempre va a ser la mejor. Y tuve yo esa idea, esa esperanza, ella va a ser la única, ella va a ser la esperanza de que algún día ella me va a sacar adelante. ¿Y ahora? Pero yo soy madre y yo la voy a sacar adelante, porque ella necesita más de mí. Hasta el último voy a luchar por ella. (...) No le pido que sea inteligente como antes, sino que al menos se detenga en algo para que se defienda." (E7): mujer, Piura, secundaria completa, pobreza extrema (indigente).

\section{Categoría 3.3. A nivel emocional}

A nivel emocional, los padres refirieron que sus hijos experimentan un conjunto de emociones a lo largo de su instancia intrahospitalaria, pues además de cuestionarse el por qué están ahí, experimentan momentos tristes, en los que extrañan su hogar, a los demás miembros de su familia y su estilo de vida. Reconocieron que el tipo de quimioterapia es un factor que influye en su estado de ánimo, pues algunas son más fuertes y les generan mayor susceptibilidad. También señalaron que sus hijos suelen temer a los procedimientos médicos, al verlos como un castigo. Refirieron preocupación en relación a que ello último repercuta en su relación con sus hijos, al creer que son los padres quienes desean hacerles daño por permitirlo. No obstante, también refirieron que cuando sus hijos se entretienen realizando actividades lúdicas, se sienten más tranquilos. 
“Ahí, un poquito decaído que está por la quimio también (...) siente que lo castigan. A nosotros nos odia a veces, cuando le pinchan, le sacan. "Te odio mamá" nos dice. Nos bota, nos saca. Y a veces a uno le hacen sentir mal. Piensa que nosotros le estamos mandando a hacer eso. Creo que le afectaría emocionalmente, en la relación con nosotros (...) Él se siente feliz al menos cuando van las niñas a hacerle jugar se siente alegre feliz (...) En quimioterapia (...) Es bien duro para los niños, al menos en mi hijo he visto que ha sufrido bastante. Al ver los punzones que le hicieron, a veces está recaído el niño.” (E6): Hombre, Tacna, secundaria completa, pobreza crónica.

“(...) Dice que va a ser doctora para picarme así como me pican. Me voy a morir para que no me veas así y me hace llorar. Cuando le sacan sangre, le cambian la vía me dice que soy mala porque dejo que le piquen, que mejor se voy a morir para que no le vea." (E11): Mujer, Cajamarca, secundaria incompleta, pobreza crónica.

“(...) ella está sacando también sus ideas de lo que está pasando acá. Pasa momentos alegres pero también pasa momentos tristes (...) ella nos ve preocupados a nosotros. Nos ve llorando y ella también se preocupa (...) Ella

ya quiere salir del hospital. Ya me dice "papito ¿cuándo nos vamos a la chacra?, ¿cuando nos vamos a pasear?" Y entonces emocionalmente está afectada (...) Ella dice “¿cuándo voy a irme al jardín? estoy enferma, perderé este año ¿al año me recibirán?" Esta preocupada en eso... pero yo le digo que tiene que mejorarse para ir a su jardín." (E2): Hombre, San Martín, secundaria completa, pobreza crónica.

Por otro lado, mencionaron que cuando sus plaquetas están altas, su ánimo también lo suele estar, por lo que hay una identificación en la relación entre el estado físico y emocional. Ello fue aludido predominantemente en las madres, lo cual guarda relación con el hecho de que ellas son quienes suelen acompañar a los hijos durante el periodo de hospitalización y tienen un mayor contacto con todo el proceso de la enfermedad y el tratamiento.

“(...) ahorita está necesitando, transfusión de sangre (...) Bajan las defensas, bajan la hemoglobina, bajan las plaquetas. Bajan su ánimo también. (...) bajan su peso (...) Cuando le ponen las plaquetas sube un poco. Ya tiene ánimo de hacer su tarea, de armar rompecabezas (...) ese día que le pusieron la quimio en la tarde ya estaba medio (...) pero de ahí le pasará pues, le choca, 
pero le pasa. Cuando le ponían los claritos no le chocaba, comía normal. La roja es la que le está chocando. Dos rojas le han puesto, esta última roja es la que le está chocando." (E12): Mujer, Ucayali, primaria completa, pobreza crónica.

En cuanto al mediano y largo plazo, se encontraron diferencias en cuanto al nivel de instrucción, siendo los padres con mayor nivel de instrucción quienes proyectaron una situación futura en base al estado actual que presentan sus hijos en la actualidad, al aludir que se sentirán limitados, temerosos e incluso deprimidos, dada la implicación de la enfermedad en su estilo de vida. Expresaron que les será difícil volver a adaptarse y que incluso más adelante, dado el posible rechazo social, no podrán encontrar una pareja estable y formar una familia. A pesar de ello, refirieron que poco a poco sus hijos irán aprendiendo a adoptar diferentes hábitos de cuidado y serán más resilientes y, sobretodo, se sentirán más tranquilos una vez que regresen a casa y tengan un tratamiento ambulatorio.

"Yo sé que más adelante le va a chocar bastante no ver a su familia acá, porque siempre jugaba con su abuelo, pero no puede el abuelo viajar. Va a ser el esfuerzo viajar. Siempre que se comunica con el abuelo, está que llora."

(E8): Hombre, Piura, secundaria completa, pobreza extrema (indigente)

"De hecho me va a decir "mamá por qué no puedo hacer esto, por qué no puedo comer esto" (...) Se va a sentir limitado en algunas cosas. Pero hay que explicarle, hay que darle conocimiento de lo que tiene." (E10): Mujer,

Lima, secundaria completa, pobreza crónica.

"Yo también temo señorita que cuando llegue a Paita, porque Paita es chiquito y todo se sabe, y de repente ella quiera enamorarse, digan "no, esa niña no porque tiene leucemia, no va a poder tener". O le van a decir "no, ella no porque ha estado con esa enfermedad, eso es lo que yo temo". Que en el futuro, cuando ella se quiera enamorar, le vayan a decir eso. Yo temo eso."

(E7): mujer, Piura, secundaria completa, pobreza extrema (indigente).

Por otro lado, padres con menor nivel de instrucción, aludieron imaginar a sus hijos más animosos, dada la supuesta mejoría en su salud, a través de la cual prima lo que desean ver en lugar de lo que es probable que suceda.

"Se va a restablecer, va a ir recuperando su ánimo." (E12): Mujer, Ucayali, primaria completa, pobreza crónica. 
“(...) también más alegre más intranquila.” (E5): Mujer, San Martín, primaria completa, pobreza crónica.

\section{Categoría 3.4. A nivel conductual}

Padres refirieron que en cuanto al apetito, hay quimioterapias que les aumenta el apetito y comen más, y por ende, suben de peso, y otras que les disminuye, por lo que comen menos. Mencionaron que cuando las maestras les brindan material lúdico, suelen interactuar con él si es que a nivel físico se sienten bien, pues si no, suelen permanecer en sus camas. Comentaron que por lo general, sus hijos hablan menos de lo usual cuando llegan al hospital, sobretodo en los primeros días. No obstante, que al ir conociendo los procedimientos y la rutina diaria, van mostrándose más abiertos al juego y a la interacción con los diferentes agentes. En general, los padres evidenciaron mayor preocupación por ver que sus hijos coman, tomen agua, jueguen, hagan sus tareas y se comuniquen, siendo estos una expresión de su mejoría.

“(...) mi hijita no ha estado comiendo, no ha estado tomando agua, y ha estado vomitando. Y estoy viendo otros casos de otros niños que no vomitan, toman bien su comidita toda, y ya me han explicado que son diferentes casos (...) pero ya me estoy dando cuenta que ella ya está poniendo de su parte, está que colabora. "Papá mira ya estoy comiendo, ya estoy comiendo mi sopita, ya no estoy vomitando" y lo que me están contando que ya está al nivel de los demás. Ya la veo más un poco más distraída, antes estaba pensando, pensando, me llamaba "papá me duele", ahorita ya no (...) Ahora está que nos llama que

ya tomó, que sí la resistió. Que le van a cambiar la vía y le digo si está tranquila y dice que sí, que ya no llora." (E8): Hombre, Piura, secundaria completa, pobreza extrema (indigente)

"Yo la veo que juega, piensa, reacciona, hace su tarea como siempre estaba haciendo en su jardín (...) cuando se cansa de jugar duerme y se levanta ya esta pensando en que vuelta va a jugar al celular o le van a hacer jugar.

Antes jugaba (...) No tiene ganas de jugar, nada (...) Conversaba, ya no quiere conversar. Ahora es solo "mami, quiero orinar". Yo le converso, pero ella no me responde, está mirando nomás (...) Menos fuerza, de tanto que están las plaquetas bajas, las defensas bajas. (...) Caminar, ya no quiere caminar. 
Ahorita no quiere comer. Ella comía harto, todo se acababa ella." (E12):

Mujer, Ucayali, primaria completa, pobreza crónica.

“(...) antes era preguntona, ahora no habla. Llegaba alguien, se le acercaba, le conversaba. (...) Cuando siente algo, se pone a llorar. No me dice ni sí ni nada, se pone a llorar más fuerte. Debe tener hambre digo (...) Ahora está cansada, hasta tres hojitas pinta y de ahí se pone molesta solita. Antes jugaba.”(E11): Mujer, Cajamarca, secundaria incompleta, pobreza crónica.

A mediano y largo plazo, padres con mayor nivel de instrucción aludieron imaginar a sus hijos teniendo dificultades para retomar la rutina a la que estaban acostumbrados, dado que requerirán mayor cuidado y estarán más limitados, pues han de protegerse continuamente de las bacterias del ambiente, debido a que sus defensas continuarán bajas. Comentaron que si bien tendrán que haber cambios en la dieta, esta se tornará más saludable. Asimismo, algunos comentaron que se tendrán que mudar a Lima, de preferencia cerca al hospital, para que así su hijo reciba el tratamiento. Otros refirieron que sus hijos no irán al colegio en unos meses, puesto que han de concentrarse en el tratamiento y controles médicos, dado que además tendrán menos fuerza física para correr y jugar, como solían tener anteriormente.

"De hecho está limitado. No va a poder comer lo que comía antes (...) se puede decir que es en un promedio como decir no larguísimo, a mediano plazo. Supongamos que tiene que llevar un tratamiento de 3 años, ahí no va a comer como yo, como come usted, tiene que llevar una dieta especial. Tiene que estar restringido de ciertas cosas. Por ejemplo, supongo yo que las frituras no se puede dar, exceso de dulces tampoco. Y harinas no sé tampoco, eso le puede cargar (...) Él tiene que tratar de llevar una vida lo más normal posible, pero saber también que tiene limitaciones. No va a poder jugar futbol, actividades

bruscas.” (E10): Mujer, Lima, secundaria completa, pobreza crónica.

No obstante, padres con menor nivel de instrucción, aludieron que retomarán la rutina practicada con anterioridad, sin dificultad, lo cual se relaciona también con la dificultad para pensar más allá en el sentido de las repercusiones que la enfermedad puede traer consigo. Así como del conjunto de implicancias que conlleva el tratamiento y los cuidados. 
"Se va a restablecer, va a ir recuperando su ánimo. Va a volver a lo que era (...) Le gustaba pintar, le gustaba ver con sus hermanos, le gustaba ver tele.” (E12): Mujer, Ucayali, primaria completa, pobreza crónica.

En cuanto al largo plazo, si bien en ambos está presente el deseo de la recuperación y el retorno al estilo de vida practicado con anterioridad, los padres con mayor nivel de instrucción, reconocen que ésta se verá mermada por las limitaciones y repercusiones de la enfermedad.

"Yo me pongo a pensar que ya no va a ser la misma niña de antes... porque ella era inteligente, ella actuaba en todo, como ella en física iba a participar en salto alto, largo, le gustaba la marinera. Ahora dicen que con esta enfermedad no se va a poder cansar tanto. Ahora ya no va a bailar la marinera como ensayaba, como le gustaba ensayar. Ya digo mi hija ya no va a ser esa niña ágil que demostraba." (E8): Mujer, Piura, secundaria completa, pobreza

$$
\text { extrema (indigente) }
$$

"Que se vaya a su jardín a la escuela, jugando. Que sea como era antes"(E5): Mujer, San Martín, primaria completa, pobreza crónica.

\section{Tema 4: Desarrollo de la enfermedad}

En cuanto al desarrollo de la enfermedad, este será descrito en base a cuatro categorías: proceso de la misma, gravedad, respuesta y factores de influencia.

\section{Categoría 4.1. Proceso de enfermedad}

En cuanto a la persistencia, los padres refirieron que el tratamiento en sí dura tres años y que al finalizar, los controles son cada vez menos continuos. Aludieron temer a que la enfermedad persista y el tratamiento se amplíe a varios años más, e incluso a toda la vida. Afirmaron que el cómo responde cada organismo al tratamiento es determinante. Y que este consta de quimioterapias y, en el caso se requiera, de un trasplante de médula ósea, lo cual los lleva, en algunos casos, a tener cierta vacilación en relación a la efectividad del tratamiento. 
“(...) supongo que será toda su vida (...) En un principio me dijeron que este proceso era de 6 meses y que en 6 meses la bebe estaba libre de esta enfermedad... y de ahí pedí que me expliquen y me dijeron que 1 año, me han dicho que 2 años y acá algunas enfermeras me han dicho que hasta 3 años... algunas que es por vida.” (E2): Hombre, San Martín, secundaria completa, pobreza crónica.

"Y si está mal, dicen que me la mandan a otro sitio o ven la compatibilidad del papá y la mamá (...) Para hacerle la médula.” (E8):

Hombre, Piura, secundaria completa, pobreza extrema (indigente)

En cuanto a la evolución, los padres aludieron que después de cuarenta días de hospitalización, el niño sale de alta para luego regresar a continuar con sus quimioterapias y controles más o menos por seis meses, hasta que poco a poco se encuentren mejorías y el doctor señale que el tratamiento sea menos continuo. Se evidenció el temor a que la enfermedad persista y a que el tratamiento no funcione.

“(...) acá nos tienen 40 días hospitalizados y ya después de eso es ambulatorio nomás. Uno tiene que venir a su cita, cada semana prácticamente. Uno no puede viajar tanto porque es a la semana. Yo creo que cuando pasan los seis meses, ya es una vez al mes así. Por eso de acá a los 6 meses me voy a quedar acá. El 27 tiene mi hijo examen de la médula, ahí van a ver si va a hacer quimio intenso o no, depende de los resultados. Si está bien, bien para nosotros, sino tiene que volverse a internar." (E6): Hombre, Tacna, secundaria completa, pobreza crónica.

Por otro lado, se evidenció una preocupación en relación a cómo será la vida de sus hijos en unos años. Se ilustró el deseo a que su hijo mejore y regrese al estado tal como se encontraba antes que se enferme. No obstante, los padres reconocieron la importancia de ser adherentes al tratamiento para que sus hijos se sientan mejor y se curen, lo cual los hace pensar en la posibilidad de mudarse a Lima para así permanecer cerca al hospital.

"Es que es depende de cómo evoluciona. Yo también me he preguntado como será la vida de mi hijo en unos años, con nosotros. Porque si continúa con este tema de leucemia y no se puede eliminar seguiremos así pues, luchándola hasta lo que se pueda (...) Ojalá que la bebe se mejore, los próximos años sea 
algo y no le pase nada." (E2): Hombre, San Martín, secundaria completa, pobreza crónica.

"Me dijeron que ella tres años tiene que seguir su tratamiento. Por eso le he dicho a mi señora que me voy a quedar acá, que hay que estar tres años porque si la llevamos a Iquitos yo no quiero que le vean así a la bebe, yo quiero así como la Valeria de antes en 3-4 años será ¿no? (...) Que no me descuide de sus citas, a un mes, a un año (...) Y continuar con el tratamiento (...)."(E4):

Hombre, Iquitos, secundaria incompleta, pobreza crónica.

En general, se evidenció que los padres con mayor nivel de instrucción contaron con información más detallada en relación a la persistencia y evolución de la enfermedad, ligada al tratamiento médico.

“Bueno viniendo para acá, lo que me digan” (E5): Mujer, San Martín, primaria completa, pobreza crónica.

"Que se le quite la enfermedad." (E11): mujer Cajamarca, secundaria incompleta, pobreza crónica

“(...) es un tratamiento largo, un tratamiento de tres años (...) seguir con su tratamiento, traerla a sus quimios, a sus controles así. Seguir así ¿no? Como el doctor lo indique." (E3): mujer, Lambayeque, secundaria completa, pobreza crónica.

\section{Categoría 4.2. Gravedad}

Los padres refirieron que si la enfermedad no se controla, se vuelve más grave, es decir, que si no se recibe el tratamiento señalado, su hijo puede fallecer. Algunos hicieron mención al tipo de leucemia, al aludir que hay subtipos y que estas conllevan a diferentes niveles de gravedad.

“(...) me dijeron que hay varias clases de leucemia (...) y ya después de los análisis me dijeron que era leucemia linfática aguda y que mayormente eso da a los niños, a los bebes (...) que el tratamiento tiene cura, no es como la otra que es mas agresiva que es la mieloide." (E3): Mujer, Lambayeque, secundaria completa, pobreza crónica. 
Cabe mencionar que la percepción sobre la gravedad de la misma también estuvo implicada cuando se habló del tratamiento, al referir que la quimioterapia puede también hacerlos fallecer.

“(...) si no lo controlas se vuelve más grave (...) si no lo controlas poco a poco, ella ... este acabándose (...) se puede morir. " (E1): Mujer, Ucayali, secundaria completa, pobreza crónica.

"Dicen que de lo bien que están, una quimio puede hacerlos fallecer. Dicen que es la quimio más fuerte que te lleva hasta la muerte (...) dice el doctor que esta enfermedad es traicionera, no tiene nada y aparece." (E11):

Mujer Cajamarca, secundaria incompleta, pobreza crónica

\section{Categoría 4.3. Respuesta}

En cuanto a la respuesta de sus hijos al tratamiento, primó el deseo de los padres de la pronta recuperación y de que la enfermedad permanezca controlada. Reconocieron que en el caso de que la quimioterapia no responda, se puede realizar el trasplante de médula; no obstante, en algunos casos, refirieron que la existencia de esta posibilidad hace que disminuya su credibilidad en la quimioterapia. A pesar de ello, se evidenció una sensación de confianza en lo que plantea el médico tratante.

Los padres manifestaron guiarse por cómo ven a sus hijos actualmente, sobretodo quienes contaron con un menor nivel de instrucción, pero también por lo que refieren padres de otros niños hospitalizados, lo cual, en ocasiones, puede hacerlos dudar acerca de la efectividad de la quimioterapia.

"Dicen que cuando no funciona la medicina le hacen transfusión de médula (....) pero no sé también cómo será. Porque dicen que lo hacen del hermano, pero ella no tiene hermano. Por eso también no entiendo porque nos dicen que la medicina y si no funciona trasplante." (E5): Mujer, San Martín, primaria completa, pobreza crónica.

Padres con un mayor nivel de instrucción refirieron que la respuesta del tratamiento no solo depende de la adherencia al tratamiento, sino también de cuánto su hijo colabore, en términos de su estado ánimo, como de su disposición para los procedimientos médicos que le realicen. 
"En el primer bloque ya han dicho que es una niña ansiosa, depresiva, que mucho lloraba, que no estaba poniendo de su parte. Y que en esta enfermedad necesita también que el paciente ponga el 50\% de su parte." (E7): Mujer, Piura, secundaria completa, pobreza extrema (indigente)

\section{Categoría 4.4. Factores de influencia}

Los padres refirieron que el tener las defensas bajas es un factor negativo influyente, dado que puede contribuir a que se adquiera más fácilmente una infección y por consiguiente el niño recaiga y se agrave la enfermedad. Es por ello que hicieron alusión a la importancia de tener un mayor control sobre el ambiente, a fin de evitar el contacto con alguna bacteria. Cabe mencionar que esta representación fue aludida en mayor medida en las madres, lo cual se vincula con su necesidad de sobreprotección.

\section{“(...) ahora a ella sus defensas van a estar bajas y no podemos}

exponerla así. Pienso que ahorita ya no, por sus defensas bajas y su enfermedad puede coger. Yo pienso que ya no va a hacer una niña normal que va a poder ir a jugar, así al suelo normal por los cuidados, que tiene que tener mas cuidado por si viene la enfermedad." (E3): Mujer, Lambayeque, secundaria completa, pobreza crónica.

Aludieron que las bacterias del ambiente pueden influir negativamente, por lo que hay que evitar su contacto, ya sea teniendo animales en casa, viajando, o no siguiendo una higiene en la desinfección de alimentos y del agua bebible, pues todo ello puede fomentar a que sus hijos se enfermen, dada la presencia de defensas bajas.

"Yo creo que estar atentos del ambiente, del viaje que haga (...) Los animales, que nosotros criamos. Eso vamos a descartarlos porque el doctor dijo que no estén cerca. De ahí no vivir en un ambiente que le pueda chocar por ejemplo el virus, el negocio de repente, en los viaje que hacemos (...)” (E6):

Hombre, Tacna, secundaria completa, pobreza crónica.

"Que le cuide, que le ponga su mascarilla siempre, a cada rato la mascarilla porque ella está delicada (...) Que no coma frutas sin lavar, lavar sus manos en cada momento (...)” (E12): Mujer, Ucayali, primaria completa, pobreza crónica. 
De igual modo, refirieron que los cambios en su estilo de alimentación los podría ayudar, por lo que seguirían una dieta más balanceada y saludable.

“(... ) tiene que comer sano, nada de aceites de nada. Frituras nada. Condimentos cero." (E1 1): Mujer Cajamarca, secundaria incompleta, pobreza crónica

Asimismo, mencionaron que el estado de ánimo es un factor determinante en cómo el niño responda al tratamiento. Padres con mayor nivel de instrucción relacionaron el estado físico con el anímico, refiriendo que si uno está deprimido tiene mayor predisposición a que las defensas bajen y consecuentemente a que se agrave la enfermedad.

“(...) si la encuentra débil y deprimida se la va a llevar rápido, depende de cómo la persona resista a su depresión." (E8): Hombre, Piura, secundaria completa, pobreza extrema (indigente)

De igual modo, afirmaron que un mayor apoyo por parte de ellos contribuye a su mejoría, al ser un aspecto que se relaciona con su estado anímico. Asimismo, se evidenció la importancia de explicarle al niño que se encuentra en un hospital y que va a recibir un tratamiento que le va ayudar a estar mejor, para disminuir su angustia. Señalaron la importancia de brindarle un mayor cuidado, pese a que sea necesario realizar cambios en su estilo de vida y lugar de residencia, como puede ser el mudarse a Lima.

“(...) el cariño, el amor de mí, de su papá (...) Que uno este pendiente de ella, demostrándole que siempre vamos a estar a su lado y todo eso ¿no?”

(E1): Mujer, Ucayali, secundaria completa, pobreza crónica.

También, manifestaron que el personal médico es un factor influyente, lo cual evidenció confianza en su desempeño. Aludieron que la comunicación constante entre todo el personal asistencial, con los pacientes y los mismos padres permite un mejor trabajo y conlleva a menores niveles de angustia y estrés.

"Sé que estoy en un hospital de garantía y sé que aquí no está cualquier persona, no está ningún doctor (...) son los especialistas en la materia.” (E2):

Hombre, San Martín, secundaria completa, pobreza crónica.

Señalaron, asimismo, que la socialización con los demás niños de la sala de hospitalización y el personal de psicología fomenta una mejor adaptación, por lo que representa de igual modo un factor de influencia. 
“(...) También que ella necesita dialogar... que converse con ustedes y que me lo relacione con los niñitos (...) Hablar con mi hija, yo quiero que se la ganen. Toda esa amargura que tiene ella, me la cambien. Yo no sabría cómo agradecerles a ustedes. Que la saquen de eso, que deje de pensar que ella ya no va ser la misma." (E7): Mujer, Piura, secundaria completa, pobreza extrema

$$
\text { (indigente) }
$$

De igual modo, los padres refirieron que el confiar en Dios es un factor influyente, pues él decidirá si sus hijos se sanarán o no. Con ello se ve la necesidad de sentirse protegidos por un ser omnipotente.

“(... ) él es el único porque como dicen lo que es imposible para el hombre para dios es posible (...) Pedirle mucho a Dios para que le de mucha sabiduría al doctor para que pueda hacer su trabajo." (E3): Mujer,

Lambayeque, secundaria completa, pobreza crónica.

A pesar de ello, los padres reconocieron que el tratamiento en sí es un factor de gran relevancia, por lo que señalaron la importancia de tener controles constantes, así como de recibir un tratamiento de forma continua. No obstante, también aludieron temer que el estar sometido de forma perenne a esta medicina les pueda generar dificultades a nivel de su desarrollo. Si bien reconocieron la posibilidad de someter a sus hijos a un trasplante, aludieron que la posibilidad de que ello suceda los conduce a una cierta desconfianza en la efectividad del tratamiento de quimioterapia, al considerar que ello puede llevarlos a la muerte.

"Sí, que hay que traerlo a su controles, recibir su quimio periódicamente. Conforme se vean mejorías y no recaídas, ya se van espaciando las visitas acá (...) estar al pie de la letra que diga el doctor.” (E10): mujer,

Lima, secundaria completa, pobreza crónica.

“(...) me preocupa por la quimio que le ponen pues... es increíble que la bebe este todo el día con ese tipo de suero... todos los días, pinchado por una o otra parte... es bien duro. Ojalá que no le tenga problemas.” (E2): Hombre,

San Martín, secundaria completa, pobreza crónica.

“A veces cuando la quimio no actúa, no mata, hay que hacer trasplante de médula (...) Sin medicamentos de repente pueda empeorar (...) Dicen que de lo bien que están, una quimio puede hacerlos fallecer. Dicen que es la quimio más fuerte que te lleva hasta la muerte." (E11): Mujer Cajamarca, secundaria incompleta, pobreza crónica 
"Por eso también no entiendo porque nos dicen que la medicina y si no funciona trasplante (...)” (E5): Mujer, San Martín, primaria completa, pobreza crónica.

\section{Tema 5: Posibilidad de cura}

En cuanto a la posibilidad de cura, esta será descrita en base a dos categorías: medicina convencional y factor místico.

Cabe mencionar que los padres no fueron excluyentes en cuanto a estas dos categorías, puesto que mencionaron ambas opciones. Respecto a esta categoría no se encontraron diferencias respecto al género, lugar de procedencia ni nivel de instrucción.

\section{Categoría 5.1. Medicina convencional}

Los padres refirieron que con el tratamiento, la enfermedad puede desaparecer dados los resultados del avance de la ciencia; no obstante, reconocieron la importancia de que continúe siendo controlada. Para ello aludieron que es necesario ser adherente y seguir las indicaciones del personal médico capacitado; sin embargo, reconocieron que el resultado dependerá también de las características individuales de cada paciente.

"Sí, porque he escuchado varios casos que se han curado. La doctora también me dijo que probablemente puede desaparecer el total, siempre va a estar controlada (...) con el tratamiento se puede desaparecer." (E1): Mujer,

Ucayali, secundaria completa, pobreza crónica.

"Las quimio lo quita lo malo, la enfermedad (...) Y que le pongan buenas medicinas para que se sane. En emergencias, los doctores nos dijeron que la enfermedad está en peligro, pero que iban a tratar de ponerle las medicinas más fuerte para que lo elimine a sus células malas.” (E5): Mujer, San Martín, primaria completa, pobreza crónica.

\section{Categoría 5.2. Factor místico}

Asimismo, aludieron que Dios los puede salvar, mediante la oración, al aspirar que un ser omnipotente lo determinará. 
“(...) Dios va a ser misericordioso. Yo me aferro a Dios, solo un milagro la va a sacar de esto (...) yo digo si de esta enfermedad sale curada, el 90\% lo hizo Dios, porque mi Dios me da esa fuerza. Porque los doctores cuando me hablan, es para derrumbarme." (E7): Mujer, Piura, secundaria completa, pobreza extrema (indigente)

“No sé, solo Dios sabe señorita (...) También encomendar mucho a Dios, tener fe en Dios.” (E12): Mujer, Ucayali, primaria completa, pobreza crónica 


\section{CAPÍTULO VI: DISCUSIÓN}

La presente investigación buscó conocer las representaciones sociales de la leucemia en padres de niños diagnosticados con esta enfermedad, por medio de entrevistas a profundidad.

La primera categoría está relacionada a la conceptualización de la leucemia, en donde la totalidad de padres la identifica como una enfermedad. En ella se ve cómo, a modo de imagen, la vinculan con aspectos internos y externos. Internos, al referirla como células cancerígenas que se expresan mediante un desorden interno y generan suciedad en la sangre, dado que contaminan y destruyen al propio organismo. Y externos, al vincularla con un virus y un animal, lo cual evidencia la necesidad de buscar la presencia de un agente externo, con cualidades de ser vivo, que ingresa al cuerpo de forma invasiva, destruyéndolo, como un modo de conceptualizar la enfermedad. Estas representaciones guardan relación a lo planteado por Perrichi (1987), quien alude que si bien cada uno crea su propia idea sobre la enfermedad, esta suele ser asociada a fenómenos internos y externos.

Al referir que son manchas negras, se ilustra la necesidad de que el cuerpo mismo brinde una señal visible que indique la aparición de la enfermedad. En general, se percibe una sensación de pérdida de control al hablar acerca de su aparición, proliferación e invasión por todo el organismo. Ello guarda relación con el estudio de Ruda (2001), quien encontró que las representaciones de ataque al cuerpo son más comunes encontrarlas en padres de hijos con leucemia, a diferencia de otras enfermedades oncológicas, al considerar el efecto físico del cáncer en el cuerpo y la falta de una tumoración sólida como parte de la sintomatología de la enfermedad.

Cabe mencionar que la representación del ataque al cuerpo, generado por el propio organismo está más presente en padres con mayor nivel de instrucción, dado que a menor nivel los padres suelen asociarlo a factores externos, buscando así visualizar la enfermedad mediante señales externas, como lo son la suciedad 
y las manchas negras en el cuerpo, lo cual se vincula a su necesidad de concretizarla.

Por tanto, los padres con mayor nivel de instrucción refieren que esta destrucción y desorganización corporal se debe a elementos propios del organismo. Ello se asemeja con lo que Ruda (2001) encontró en su estudio, al referir que a mayor nivel de instrucción, los padres suelen asociar el cáncer con variables internas, siendo estas el factor hereditario, el caos corporal y el ataque al cuerpo.

A pesar del desconocimiento previo al diagnóstico de la leucemia, se observa, en general, la necesidad de buscar una explicación al conjunto de síntomas experimentados, a fin de paliarlos y darles un tratamiento. En ello, se ve la influencia del lugar del que proceden los padres y de los elementos culturales predominantes de cada contexto, pues tal como menciona Gil (2000), las representaciones están determinadas por creencias culturales, las cuales influyen en la percepción y actitud de los pacientes y familiares de los mismos.

En padres provenientes de la Selva, a diferencia de los de la Costa y la Sierra, se ve un mayor desconocimiento acerca de los recursos de prevención de salud y una mayor demora en acudir a hospitales y centros de salud, pues tal como aluden Mabit (1993) y Graña (2013), dado el fuerte enraizamiento cultural, la riqueza herbaria y el bajo costo económico, las personas suelen acudir a los centros de salud cuando se agotan las posibilidades que le ofrecen las prácticas de sanación autóctonas en las que se les brinda medicina natural, razón por la cual ésta sigue siendo el principal sistema que opera en esta región.

Todo ello se ajusta a la idea de que las personas suelen relacionar la información nueva con lo que ya conocen y con lo que su contexto da como válido, pues tal como Moscovici (1961) refiere, las representaciones permiten crear nueva información en relación al mundo en que viven a partir de lo que ya conocen. Y también con lo que plantea Jodelet (1991), al mencionar que estas representaciones surgen de las experiencias personales y de la información brindada por el bagaje cultural.

En relación a la segunda categoría, la cual trata acerca de las causas de la leucemia, los padres suelen atribuirla a factores biológicos (internos) y 
ambientales (externos) (Ruda, 2001; Monteza y Vera, 2013). Tal como sucede en términos de la conceptualización, se ha visto que a mayor nivel de instrucción hay una tendencia a buscar una explicación por medio de un carácter interno, lo cual se relaciona con la capacidad de considerar elementos no visibles como los desencadenantes, tal como sucede con la vida intrauterina y el factor hereditario. Ello, a su vez, llega a traducirse en un sentido de culpabilidad, sobretodo en el caso de las madres, dado que ante la necesidad de encontrar la causa exacta, llegan a atribuirse a sí mismas la responsabilidad de la aparición de la enfermedad. Esto se relaciona con lo que Ruda (2001) encontró en su estudio, al aludir que los padres suelen compartir un sentimiento de responsabilidad frente a este hijo que nace enfermo o con predisposición para desarrollar el mal. Y con lo que plantea Ajuriaguerra y Macelli (1987), al referir que ciertas teorías etiológicas son desarrolladas por los padres con el fin de encontrar una explicación, ya sea asumiendo todo el peso de la transmisión de la enfermedad por parte de uno de ellos o negando toda la carga hereditaria.

En cuanto a los factores ambientales (externos), los padres hacen alusión a la influencia del clima, las condiciones sanitarias, la ingesta de sustancias y la alimentación. Así como al impacto de la disfuncionalidad familiar y las creencias místicas y religiosas. En el caso del clima, por ejemplo, los padres señalan el carácter de incontrolabilidad que ello conlleva; no obstante, cuando se habla de la contaminación, se ve un sentido de culpabilidad inminente al referir que la enfermedad se deriva dada la exposición de ambientes contaminantes, productos y sustancias tóxicas. No obstante, también hay una necesidad de justificar su incontrolabilidad y señalar el desconocimiento sobre el impacto negativo que ello les podía generar para así disminuir el sentimiento de culpa.

Cuando se habla de las condiciones sanitarias, se ve la falta de conocimiento acerca de la importancia de la higiene en el uso diario, lo cual entra a tallar dentro de la promoción de la salud, puesto que se relaciona con la falta de asistencia a servicios preventivos. Respecto a la ingesta de sustancias medicinales, esta es representada mediante un agente externo que ingresa y desorganiza el conjunto de elementos en el cuerpo, generando un daño interno. En ese sentido, se ve un menor sentido de culpabilidad al ser estas sustancias otorgadas en centros de salud, pues deslinda su responsabilidad como padres. 
Esta noción de lo sanitario está presente en todos los grupos representacionales, al considerar el género, lugar de procedencia y nivel de instrucción distintos.

Respecto a la alimentación, señalan como principal factor la discontinuidad en la ingesta de leche, lo cual se vincula con la lactancia materna y ello a su vez con la relación materno-filial. Ello les genera, sobretodo a las madres, un sentimiento de culpabilidad dada la responsabilidad que se atribuyen, al ser ellas las proveedoras principales de alimento en sus hijos. Asimismo, se ve este sentido de culpabilidad al mencionar no haberles brindado suplementos alimenticios ni una alimentación balanceada. A pesar de ello, se ve una necesidad de justificar el tipo de alimentación proporcionada, a fin de amilanar esta culpa y la idea de haberse descuidado de ellos. Si bien en ambos padres se ve este sentimiento de culpa, las mujeres y los hombres lo trabajan de diferente manera para así reducir su impacto emocional. Mientras los padres suelen deslindar la responsabilidad hacia las madres, culpabilizándolas; estas refieren que hicieron todo lo que pudieron para que sus hijos coman bien, pero que estos no las obedecieron, por lo que deslindan la responsabilidad también.

Ello guarda relación con lo que plantea Ajuriaguerra y Marcelli (1987), al referir que cuando el paciente es un niño, los padres suelen elaborar teorías sobre el origen de la enfermedad, tendiendo incluso a atribuirse a sí mismos la responsabilidad y, en otras, a proyectarla sobre su pareja como un medio de reducir la culpa que pueden llegar a sentir.

En relación a funcionalidad familiar, si bien los conflictos en la dinámica conyugal les generan culpabilidad, buscan disminuir su impacto al mencionar que el otro miembro de la pareja fue el responsable en fomentar estas discusiones, buscando volcar al otro la responsabilidad de la aparición de la enfermedad. Ello se observa predominantemente en las madres, quienes extrapolan este sentimiento de culpa en su pareja, pues les es inconcebible que el cuidado que les proporcionaron a sus hijos les haya hecho daño, dado que se opone a su rol protector. De manera distinta sucede con la sobreprotección, al aludir que mediante este cuidado excesivo esperaban que sus hijos se desarrollen con total normalidad; no obstante, el no haber sido así, las hace sentir culpables. Ello se asemeja a lo afirmado por Perrichi (1986), al referir que dado que los sentimientos de responsabilidad y culpa son difíciles de manejar, los padres 
llegan a concebir a la enfermedad como producto de la negligencia o una manifestación de un amor insuficiente.

La causalidad también entra a tallar en el azar, lo místico y lo religioso. Si bien algunos padres atribuyen la enfermedad al destino, al verla como algo externo y ajeno a ellos; otros que la vinculan con una prueba y/o castigo de un ser superior, como parte del resultado de sus propias acciones, lo cual llega a traducirse en un sentimiento de culpabilidad en ellos mismos.

Al decir que es una prueba de Dios, es como si liberaran esa culpa y carga de que han sido castigados por un ser superior a fin de disminuir el impacto emocional que les podría generar. Los padres son quienes más refieren el castigo divino como factor causal; mientras que en el caso de las madres, la prueba de Dios es la aludida con mayor frecuencia.

Esta concepción se asemeja con la hallada en los diversos estudios (Ruda, 2001; Giraldo-Mora, 2009; González, Fonseca y Jiménez, 2006; Die, 2006; Monteza y Vera, 2013; Sánchez, Llano y Guerrero, 2013), dado que bajo este contexto, la enfermedad es considerada como una experiencia que le permite a las personas reflexionar sobre sus actos e interpretar esta situación como un modo de purga que les permite enmendar sus errores y rectificarse, frente a un ser todopoderoso castigador que intenta recuperar el orden y la conciencia social a través del sufrimiento y la culpabilidad.

De por sí, la culpa es un sentimiento que tiende a ser expresado de manera indirecta y que aparece con mayor fuerza cuando los padres empiezan, luego del primer momento del diagnóstico, a buscar explicaciones a la enfermedad de sus hijos (Ruda, 2001), pues tal como plantean Nouvillas y Huici (1990), ante la incertidumbre, las personas buscan comprender las causas, como un modo de ganar control sobre la situación que experimentan, dado que es un aspecto lógico del pensamiento social (Vega, 2011 citado en Monteza y Vera, 2014). Cabe mencionar que es ahí donde las creencias culturales entran a tallar, al darle un sentido a la afección que padecen (Leventhal et al., 1980; Sloper, 2000; Boman et al., 2003; Brown et al., 2003).

Todo ello guarda relación con lo que propone Grau (2002) al referir que la reacción de los padres suele ir acompañada de sentimientos de angustia, 
hostilidad, autocensura y culpa, dado que se sienten a menudo responsables de la enfermedad de su hijo y cuestionan su capacidad para protegerle. Es por ello que ante la incertidumbre que les genera la situación misma, se atribuyen en parte la responsabilidad, como un modo de disminuir la ansiedad ante la falta de control de las situaciones por las que atraviesan. Por tanto, tal como refiere Weiner (1992), el sentimiento de culpa se experimenta cuando la causalidad de un fenómeno es atribuido a variables internas y controlables, dado que bajo esa premisa, uno mismo es el responsable de su aparición, a diferencia de cuando se alude a un fenómeno externo e incontrolable.

Por ende, cuando se habla de causalidad, hay padres que atribuyen esta enfermedad a causas biológicas (internas), vinculándolas muchas veces con ellos mismos, pues al no encontrar una respuesta se responsabilizan por ello, generándoles así un sentimiento de culpa, y también hay otros que la vinculan a un agente externo, lo cual hace que disminuya su sentimiento de culpabilidad. Ello es similar a lo que propone Perrichi (1987), al referir que existen dos concepciones diferentes sobre el origen de la enfermedad, ya sea que este se da debido a la presencia de un agente externo o bien ya se encuentra dentro del organismo antes de manifestarse.

En relación a la tercera y cuarta categoría, las cuales tratan acerca de las consecuencias y el desarrollo de la enfermedad, se puede ver que en relación a la situación actual que presentan sus hijos, las madres suelen aludir con mayor complejidad a los cambios físicos, emocionales y conductuales que sus hijos presentan durante el periodo actual de hospitalización, a diferencia de los padres, dado que son ellas quienes suelen acompañar a sus hijos a lo largo de la instancia intrahospitalaria. En el caso de los padres, si bien son conscientes de los cambios a nivel del apetito, peso y del surgimiento de sentimientos de tristeza y enojo que experimentan sus hijos, las madres evidencian mayor sensitividad. Ello se vincula a lo que Caballero (2012) encontró en su estudio, al referir que dado que las madres pasan la mayor cantidad de tiempo acompañando a sus hijos en sus hospitalizaciones y tratamientos, hay un mayor involucramiento afectivo y por tanto una mayor atención a los cambios físicos y emocionales que experimentan sus hijos. 
De igual modo, las madres identifican con mayor facilidad los cambios del comportamiento de sus hijos, derivados de las alteraciones emocionales generadas por el proceso de hospitalización y los efectos mismos del tratamiento. Ello se asemeja a lo encontrado en Lafaurie et al. (2009), quienes señalan que es recurrente que las madres se preocupen por el impacto emocional que les genera a sus hijos las diferentes situaciones por las que atraviesan a lo largo de la instancia intrahospitalaria, siendo la ansiedad y la depresión lo que suele estar más presente en ellos.

A diferencia del corto plazo, en donde la experiencia directa es la que entra a tallar en su percepción, en relación al mediano y largo plazo se ve un gran temor a que la enfermedad progrese, por lo que desean que el tratamiento cubra sus expectativas y sus hijos puedan recuperarse de la enfermedad. Si bien hay un anhelo por recobrar el estilo de vida practicado con anterioridad, la gran mayoría reconoce que esta deberá estar sometida a algunas limitaciones.

Ello se asemeja en gran medida a lo encontrado por Lafaurie et al. (2009) al señalar que el anhelo de las madres suele estar vinculado al éxito del tratamiento y al retorno del funcionamiento cotidiano de la dinámica familiar, por lo que destinan todos sus esfuerzos en mantenerse adherentes al tratamiento de sus hijos y en brindarles los cuidados necesarios, lo cual se ilustra en el suministro de una alimentación balanceada, medidas de higiene y en la forma adecuada de aislarlos para prevenir que se enfermen, dada la condición médica que presentan.

En relación al mediano plazo, ambos padres muestran preocupación acerca del impacto que la enfermedad puede generarles en relación a su desarrollo a nivel físico, la cual va ligada a la importancia de mantener una adherencia al tratamiento y un estilo de vida más saludable. En cuanto al desarrollo cognitivo, este resulta ser una variable aludida únicamente en los padres con mayor nivel educativo. A nivel emocional, si bien hay un deseo de que sus hijos se recuperen en su totalidad, está presente la preocupación de que el nuevo estilo de vida adoptado impacte de manera negativa en su estado de ánimo, al estar expuesto a grandes limitaciones, dada la enfermedad y los cuidados del tratamiento. Ello coincide con lo encontrado en Salguero (2014), 
quien refiere que a los padres les es difícil pensar en un futuro la posibilidad de que el impacto emocional de la enfermedad perdure y se acreciente en sus hijos.

Si bien a mayor nivel de instrucción, hay una mayor conciencia acerca de las repercusiones negativas en el estado físico, estado anímico, nivel cognitivo y de las limitaciones conductuales que conlleva la enfermedad, hay un deseo inminente de recuperación que va ligado a la posibilidad de cura.

El deseo de una recuperación a largo plazo está presente en todos los padres, dado que hay un temor a que la enfermedad perdure e incluso se incremente, a pesar de ser conscientes de su gravedad. Cabe mencionar que el temor acerca de las posibles secuelas del tratamiento a nivel del propio desarrollo también está presente, por lo que la adherencia al mismo ha de ser trabajada constantemente con ellos.

Siendo el nivel de instrucción, un factor influyente en lo que respecta a su capacidad de proyectar una situación futura, los padres con mayor nivel educativo suelen imaginarla más acorde a la situación actual por la que atraviesan sus hijos, al considerar en mayor medida las limitaciones y repercusiones que ello les puede generar a mediano y largo plazo.

Respecto a la evolución de la enfermedad, se ve un mayor conocimiento cuando se habla del tratamiento en los padres, a diferencia del desarrollo de la enfermedad, puesto que, en parte, ello se vincula al contacto directo que tienen con el contexto hospitalario, los procedimientos médicos y las medicinas. No obstante, también con el impacto emocional que les genera el pensar en la evolución de la enfermedad, dado que ello va acompañado de incertidumbre y de la posibilidad de que se agrave y su hijo fallezca, lo cual es sumamente difícil de imaginar para ellos.

Esto, se asemeja a lo planteado por Ajuriaguerra (1977), al proponer que los padres al intentar defenderse contra la angustia de que su hijo tenga una enfermedad grave, evitan incorporar sus emociones en sus relatos de su vida imaginaria, a fin de evitar caer en un riesgo depresivo.

Vinculado a ello, tal como se encontró en estudios similares (Ochoa y Polaino-Lorente, 1999; Sloper, 2000; Streisand, Braniecky, Tercyak y Kazak, 2001; Vrijmoet-Wiersma et al., 2008; Moral, Segura, García y Téllez, 2012; 
Rodriguez et al., 2012; Mejía, 2013), es común que la enfermedad oncológica esté asociada a altos niveles de estrés, dada la vivencia de situaciones en las que la incertidumbre se sitúa como principal elemento en relación a la evolución (duración y consecuencias) de la enfermedad, los cuidados requeridos y la preocupación acerca del manejo de la comunicación con sus hijos, puesto que ello plantea desafíos para la parentalidad y genera cambios a nivel de la dinámica familiar (Lafaurie et al., 2009; Grau y Espada, 2012; Sánchez et al., 2013).

En relación a la quinta categoría, la cual hace referencia a la posibilidad de cura, resulta interesante ver cómo es que los padres van incorporando la medicina y los tratamientos en su repertorio, de tal manera que llegan a considerar la posibilidad de quedarse en Lima con su hijo, a fin de continuar con los tratamientos médicos indicados y a confiar en lo referido por los doctores, a fin de lograr su mejoría, a pesar de haber dudado anteriormente, en algunos casos, de su capacidad, al compararlos con los curanderos. Ello se vincula a lo que Ruda (2001) propone en su estudio, al referir que los elevados niveles de angustia de los padres y la sensación de vulnerabilidad generada los conduce a aferrarse a las posibilidades que se les ofrece, lo cual hace que en ocasiones las idealicen, puesto que aún no han tenido el tiempo suficiente para confiar en el tratamiento por su propia experiencia.

No obstante, ello no implica el abandono de sus creencias, ya sean culturales como religiosas, puesto que estas les genera seguridad y los exime de alguna forma de las consecuencias derivadas de la enfermedad y el tratamiento, al brindarles una sensación de protección omnipresente, lo cual va más allá de lo que la ciencia les ofrece, dado que la fe religiosa, al ser vista como una estrategia de negociación para sobrevivir al cáncer, permite brindarles una sensación de seguridad y confianza en el ser divino, para así evitar experimentar sentimientos de miedo al futuro, logrando así transformar su fragilidad en fortaleza y la vulnerabilidad en resiliencia (Aquino y Zago, 2007; Fletcher, Schneider y Harry, 2010; Monteza y Vera, 2014; Sánchez et al., 2013; Salguero, 2014).

En ello se ve cómo los padres, independientemente de su lugar de procedencia y nivel de instrucción, incorporan dentro de su bagaje cultural este 
nuevo conocimiento, el cual les brinda una posibilidad de cura. Todo ello se relaciona con lo que Jovchelovitch (2007) y Moscovici (1961) plantean acerca de la transformación de los saberes sociales, al referir que pueden coexistir las creencias y conocimientos previos propios del lugar en que proceden con los brindados por el nuevo contexto, en este caso, el hospitalario. 


\section{CONCLUSIONES}

- En cuanto a la conceptualización de la leucemia, los padres la describen como una enfermedad grave que puede llevarlos a la muerte y que se desencadena por un desorden interno, generado por variables internas o externas que contribuyen a la destrucción del organismo. En general, se ilustra la sensación de pérdida de control al hablar acerca de su aparición, proliferación e invasión por todo el cuerpo.

- En relación a explicaciones previas de la leucemia, se ve la influencia del lugar de procedencia, puesto que las representaciones sobre salud y enfermedad varían en relación a ello y también en función de la propia experiencia.

- En cuanto a los conocimientos previos de la enfermedad, se ve un desconocimiento en relación a la promoción y prevención de salud, así como la falta de acceso a centros de salud, sobretodo en padres de la Selva peruana, pues suelen acudir previamente a curanderos y a la medicina natural.

- El conocimiento propio de la enfermedad suele ser más complejo a medida que se incrementa el nivel de instrucción de los padres, lo cual les permite tener un entendimiento más preciso y certero en relación a lo que les plantea el personal de salud.

- En cuanto a las causas de la leucemia, los padres con un mayor nivel de instrucción, aluden que ésta se da debido a factores biológicos; mientras que padres con un menor nivel de instrucción, la relacionan con variables externas.

- El no saber con certeza por qué se origina esta enfermedad los lleva a muchos a atribuirse a sí mismos la responsabilidad de su aparición y a sentirse culpables, sobretodo en el caso de las madres.

- En cuanto a las consecuencias y al desarrollo de la enfermedad, las madres, al ser quienes suelen acompañar a sus hijos a lo largo de la instancia intrahospitalaria, suelen tener una representación más precisa y compleja en relación a los cambios físicos, emocionales y conductuales que experimentan sus hijos. 
- Los padres con mayor nivel de instrucción son más capaces de incorporar en sus proyecciones a mediano y largo plazo la repercusión y las limitaciones que puede generar la enfermedad misma y el tratamiento.

- Si bien hay un anhelo por recuperar el estilo de vida practicado con anterioridad, la gran mayoría de padres es consciente de que éste deberá estar sometido a algunas limitaciones.

- Respecto a la evolución de la enfermedad, si bien no hay un claro conocimiento en relación al desarrollo de la misma, sí lo hay en relación al tratamiento, lo cual se vincula con el impacto emocional que ello trae consigo.

- En relación a la posibilidad de cura, se evidencia cómo los padres se aferran a los nuevos tratamientos que les ofrece la medicina convencional, sin dejar sus creencias de lado, con tal de que sus hijos se recuperen. 


\section{RECOMENDACIONES}

A continuación se detallarán las recomendaciones según los resultados:

- Continuar realizando estudios bajo la misma línea de investigación, para promover un mayor conocimiento en el campo de la psicooncología.

- Realizar estudios comparativos acerca de las representaciones sociales sobre la leucemia y el cáncer en general en padres de niños hospitalizados en instituciones tanto del ámbito público como del privado, a fin de tener una mayor complejidad en los resultados, en relación a las variables sociodemográficas.

- Realizar estudios acerca de las representaciones sociales sobre la quimioterapia, a fin de relacionar la información que se encuentre con la de representaciones sobre la enfermedad, a fin de prever el tipo de adherencia al tratamiento que se tendrá.

- Realizar estudios comparativos sobre el sentido de culpabilidad y el estilo de afrontamiento entre las madres y los padres de niños hospitalizados, a fin de proveerles un mejor soporte socioemocional que permita abordar de manera más adecuada el proceso de enfermedad de sus hijos.

- Realizar estudios exploratorios sobre las representaciones acerca del origen de la leucemia en padres provenientes de la Selva peruana, a fin de identificar creencias y crear estrategias para fomentar la adherencia al tratamiento de medicina convencional.

- Realizar un estudio comparativo entre la adherencia al tratamiento y el nivel de instrucción en padres de niños con leucemia, a fin de explorar de qué manera integran sus representaciones en base a dichas variables.

- Realizar constantemente programas psicoeducativos a los padres acerca de la leucemia, a fin de crear mayor conciencia sobre la enfermedad y fomentar una mayor adherencia al tratamiento.

- Crear un manual psicoeducativo para los padres acerca de la leucemia y la quimioterapia, en el cual se incorporen los tratamientos de la medicina moderna a las representaciones que ellos tienen sobre la salud y la enfermedad, a fin de promover una adecuada adherencia al tratamiento.

- Sensibilizar al personal de salud acerca del proceso de aceptación de los padres acerca de la enfermedad de sus hijos, dado que ellos son una variable de influencia en la adherencia al tratamiento, así como en la actitud que tomen hacia la misma. 


\section{REFERENCIAS}

Ajuriaguerra, J. (1977). Manual de Psiquiatría Infantil. Barcelona: Masson.

Ajuriaguerra, J. y Marcelli, D. (1987). Manual de Psicopatología del Niño. Barcelona: Masson.

Andrykowski, M., Brechting, E., Graue, L., Gochett, C., Lykins, E. y Roach, A. (2008).

Beliefs about cancer causation and prevention as a function of personal and family history of cancer: a national, population-based study. Psycho-Oncology, 17(10), 967-974. doi: 10.1002/pon.1306

Aquino, V. y Zago, M. (2007). O significado das crenças religiosas para um grupo de pacientes oncológicos em reabilitação. Revista Latino-Americana de Enfermagem, 15(1), 42-47. Recuperado de http://www.scielo.br/scielo.php?script=sci_arttext\&pid=S0104$11692007000100007 \& \operatorname{lng}=\mathrm{en} \& n \mathrm{~nm}=\mathrm{iso} \& \operatorname{tlng}=\mathrm{en}$

Arbeláez, M. (2002). Las representaciones mentales. Revista de Ciencias Humanas, (29). Recuperado de http://www.utp.edu.co/ chumanas/revistas/revistas/rev29/arbelaez.htm

Boman, K.; Lindahl, A. y Björk, O. (2003). Disease-related distress in parents of children with cáncer at various stages after the time of diagnosis. ActaOncológica, 42(2).137-146. Recuperado de https://www.researchgate.net/publication/10713389_Diseaserelated_Distress_in_Parents_of_Children_with_Cancer_at_Various_Stages_afte r_the_Time_of_Diagnosis

Brown, R.; Madan-Swain, A. y Lambert, R. (2003). Posttraumatic stress symptoms in adolescent survivors of childhood cancer and their mothers. Journal of Traumatic Stress, 16(4), 309-318. Recuperado de http://onlinelibrary.wiley.com/doi/10.1023/A:1024465415620/abstract

Caballero, M. (2012). Sensitividad en madres de niños con cáncer de entre 3 y 5 años de edad (tesis para optar el título profesional de Licenciado en Psicología). Pontificia Universidad Católica del Perú.

Caldas, O. (2014). Representaciones del cáncer en pacientes oncológicos jóvenes (tesis para optar el título profesional de Licenciado en Psicología). Pontificia Universidad Católica del Perú.

Calman, K. (1982). The care of advanced disease and psychological factors. En Halnan, K. (Ed.), Treatment of cancer (pp.789-796). Nueva York: Igaku-Shoin.

Castaño A., Krikorian A., Vargas J. y Vélez, M. (2009). El sufrimiento en pacientes con cáncer. En Oblitas, L. y Palacio, X. Psicooncología: Intervención Psicológica en el Cáncer (pp.128-140). Bogotá: Psicom editores.

Castaño, A. y Palacios- Espinosa, X. (2013). Representaciones sociales del cáncer y de la quimioterapia. Psicooncología, 10(1), 79-93. Recuperado de http://revistas.urosario.edu.co/index.php/apl/article/viewFile/3287/3037

Die, M. (2006). Impacto Psicosocial del Cáncer. Revista de la Sociedad Española de Oncología Médica, 1(2), 19-21. Recuperado de http://www.seom.org/seomcms/images/stories/recursos/infopublico/publicacione s/revista_contigo/n_6/psicooncologia.pdf

Domínguez, C. (2012). Construcción de la Adherencia. Estrategias de intervención desde el Trabajo Social con personas en tratamiento para tuberculosis. Margen: revista de trabajo social y ciencias sociales, (7), 1-12. Recuperado de http://www.margen.org/suscri/margen67/dominguez.pdf 
Evans, D. y Norman, P. (2009). Illness representations, coping and psychological adjustment to Parkinson's disease. Psychology and Health, 24(10), 1181-1196. doi: 10.1080/08870440802398188

Fletcher, P., Schneider, M. y Harry, R. (2010). How do I cope? Factors affecting mother's abilities to cope with pediatric cancer. Journal of Pediatric Oncology Nursing, 27(5), 285-298. doi: 10.1177/1043454209360839

Gallego, R. (1995). Discurso constructivista de las tecnologías. Bogotá: Libros y libres S.A.

Gil, F. (2000). Manual de Psicooncología. Madrid: Nova Sidonia Oncología

Giraldo-Mora, C. (2009). Persistencia de las representaciones sociales del cáncer de mama. Revista de Salud Pública, 11(4), 514 - 525. doi: http://dx.doi.org/10.1590/S0124-00642009000400003

Goisin, A. (2014). Médico, paciente y familia. Relaciones saludables. Comunicación presentada en la XII Jornada del Departamento de Psiquiatría y Salud Mental, 15 de noviembre (pp.1-7). Buenos Aires: Universidad de Buenos Aires.

Recuperado de http://www.fmed.uba.ar/depto/saludmental/jornada/2014/5.2.pdf

González, O., Fonseca, J. y Jiménez, L. (2006). El cáncer como metáfora de muerte o como opción para resignificar la vida: narrativas en la construcción de la experiencia familiar y su relación con el afrontamiento del cáncer de un hijo menor de edad. Diversitas, 2(2), 259-277. Recuperado de http://www.scielo.org.co/scielo.php?script=sci_arttext\&pid=S179499982006000200007

Graña, D. (2013). Concepciones sobre la salud en un grupo de curanderos de la Selva Peruana. (Tesis de Licenciatura). Pontificia Universidad Católica del Perú.

Grau, C. (2002). Impacto Psicosocial del Cáncer Infantil en la Familia (versión electrónica). Diversitas, 5(2), 87-106. Recuperado de https://www.researchgate.net/publication/270889950_IMPACTO_PSICOSOCI AL_DEL_CANCER_INFANTIL_EN_LA_FAMILIA

Grau, C. y Espada, M. (2012). Percepciones de los padres de niños enfermos de cáncer sobre los cambios en las relaciones familiares. Psicooncología, 9(1), 125-136.

Recuperado de http://revistas.ucm.es/index.php/PSIC/article/viewFile/39142/37747

Guana, A. (2011). Factores psicosociales en familias de niños con cáncer: abordaje desde la Psicooncología Pediátrica en Colombia. En Oblitas, L. y Palacio, X. Psicooncología: Intervención Psicológica en el Cáncer (pp. 76-99). Bogotá: Psicom editores.

Hale, E., Treharne, G. y Kitas, G. (2007). The common-sense model of self-regulation of health and illness: how can we use it to understand and respond to our patients' needs. Oxford University Press, 46(6), 904-906. doi:10.1093/rheumatology/kem060.

Hallford, G. (1993). Children's understanding: the development of mental models. New Jersey: Lawrence Erlbaum Associates.

Hernández, R., Fernández, C. y Baptista, P. (2010). Metodología de la investigación. México D.F.: McGraw-Hill Education.

Hernández, R., Fernández, C. y Baptista, P. (2014). Metodología de la investigación. México D.F.: McGraw-Hill Education.

Heidrich, S., Phelan, C. y Rhea, H. (2009). Older Breast Cancer Survivors' Symptom Beliefs. Oncology Nursing Forum, 36(4) 463-470. Recuperado de http://www.ncbi.nlm.nih.gov/pubmed/19581237

Hetje R., Lechner, L. y Vollink, T. (2008). The role of illness representations in coping 
and health of patients treated for breast cancer. Psycho-Oncology, 18(8), 849857. doi: $10.1002 /$ pon. 1488

Huapaya, N. (2004). Representaciones de las relaciones de pareja en jóvenes universitarios. (Tesis de Licenciatura). Pontificia Universidad Católica del Perú.

Iglesias, S, Fabelo, R. y Miranda, R. (2005). Representación social de algunas enfermedades crónicas a nivel comunitario. Conferencia presentada en el $\sigma^{o}$ Congreso Virtual de Psiquiatría. Recuperado de http://www.psiquiatria.com/bibliopsiquis/handle/10401/3409

Instituto Nacional de Enfermedades Neoplásicas (2014). Indicadores Anuales de Gestión INEN-2014. Recuperado de http://www.inen.sld.pe/portal/documentos/pdf/estadistica/datos_estadisticos/201 50409_Indicadores_Anuales_de_Gestion_INEN_2014.pdf

Instituto Nacional de Enfermedades Neoplásicas. (2015a). Perfil Epidemiológico. Recuperado de http://www.inen.sld.pe/portal/estadisticas/datosepidemiologicos.html

Instituto Nacional de Enfermedades Neoplásicas. (2015b). Ficha Social. Lima: Instituto Nacional de Enfermedades Neoplásicas.

Jodelet, D. (1986). La representación social: fenómenos, concepto y teoría. En: Moscovici, S. (comp.). Psicología Social II. Pensamiento y vida social. Psicología social y problemas sociales, 380-753. Barcelona: Paidós.

Jodelet, D. (1991). Representaciones sociales: un área en expansión. En D. Paez (Ed.) SIDA: Imagen y prevención, (pp. 25-56). Madrid: Fundamentos.

Jovchelovitch, S. (2007). Knowledge in Context. Nueva York: Routledge.

Kvale, S. (2008). Qualitative inquiry between scientistic evidendialism, ethical subjectivism and the free market. International Review of Qualitative Research. 1, 5-18. Recuperado de http://psy.au.dk/fileadmin/site_files/filer_psykologi/dokumenter/CKM/NB40/in quiry_sk.pdf

Lafaurie, M., Barón, L., León, D.;...Roncancio, M. (2009) Madres Cuidadoras de niños (as) con cáncer: vivencias, percepciones y necesidades. Revista Colombiana de Enfermería, 5(1), 41-52. Recuperado de http://www.uelbosque.edu.co/sites/default/files/publicaciones/revistas/revista_co lombiana_enfermeria/volumen5/madres_cuidadoras_ninos_cancer.pdf

Ladino, L. (2011). Creencias y prácticas sobre la tuberculosis en un grupo de pacientes y sus familiares de la ciudad de Bogotá, D. C. Una aproximación cualitativa (tesis de maestría). Universidad Nacional de Colombia.

Leventhal, H., Meyer, D. y Nerenz, D. (1980). The common sense representations of illness danger. New York: Pergamon Press.

Llinares, L., Benedito, M., y Piqueras, A. (2010). El enfermo de cáncer: una aproximación a su representación social. Psicología \& Sociedade, 22(2), 318327. Recuperado de http://www.scielo.br/pdf/psoc/v22n2/12.pdf

Lombardo, E. y Monchietti, A. (2015). Niveles de conocimiento que integran las representaciones sociales. Un estudio sobre polifasia cognitiva. Perspectivas en Psicología, 12(2), 50-56. Recuperado de https://dialnet.unirioja.es/servlet/articulo?codigo $=5294243$

López-Huerta, J. Álvarez-Bermúdez, J. y González-Romo, R. (2012). La experiencia psicosocial de padres de hijos con leucemia en un hospital público de la ciudad de San Luis Potosí. Psicooncología, 9(1), 137-150. doi: 10.5209/rev_PSIC.2012.v9.n1.39143.

Mabit, J. (1993). Cuidado Tradicional de la Salud en San Martín. Takiwasi. 1-3. 
Recuperado de

http://www.takiwasi.com/docs/arti_esp/cuidado_tradicional_salud.pdf

Mejía, M. (2013). Estresores relacionados con el cáncer, sentido de coherencia y estrés parental en madres de niños con leucemia que provienen del interior del país (tesis de maestría). Pontificia Universidad Católica del Perú.

Ministerio de Salud del Perú (2013). Análisis de la Situación de Cáncer en el Perú. Recuperado de: http://www.dge.gob.pe/portal/docs/asis_cancer.pdf

Moldovan, R. (2009). An analysis of the impact of irrational beliefs and illness representations in predicting distress in cancer and type II diabetes patients. Cognition, Brain, Behavior. An Interdisciplinary Journal, 13(2), 179-193. Recuperado de http://www.scipio.ro/documents/11506/4faa1fea-3e8f-4861b3b7-a67f2dd534d5

Monteza S. y Vera, L. (2013). Representación Social del Cáncer: Un Estudio desde la Perspectiva del Adolescente Diagnosticado con Leucemia-Chiclayo, Perú (tesis para optar el título profesional de Licenciado en Psicología). Universidad Católica Santo Toribio de Mogrovejo.

Moral, J., Segura, L., García, E. y Téllez, A. (2012). Estrés y calidad de vida relacionada con la salud en padres de niños con Leucemia Linfoblástica Aguda. Psicogente, 15(28), 249-261. Recuperado de http://publicaciones.unisimonbolivar.edu.co/rdigital/ojs/index.php/psicogente/art icle/view/360

Moscovici, S. (1961). El psicoanálisis, su imagen y su público. Buenos Aires: Huemul.

Moscovici, S. (2001). Social Representations: Exploration in Social Psychology. Nueva York: New York University Press.

Nouvilas, E. y Huici, C. (1990). Atribución social y cumplimiento terapéutico. En S. Barriga, J.M. León, M.F. Martínez y F. Jiménez. Psicología de la Salud: Aportaciones desde la Psicología Social, (pp.270-295). Sevilla: Sedal.

Ocampo, L., Peñaloza, M., Sarmiento, D., y Hernández, D. (2014). Impacto de la relación profesional - paciente en la conducta de adherencia al tratamiento en personas con labio y paladar hendido de una Clínica Odontológica en la ciudad de Bogotá. (Tesis de Licenciatura). Pontificia Universidad Javeriana.

Ochoa, B. y Polaino-Lorente, A. (1999). El estrés de los padres como consecuencia de la hospitalización de sus hijos: una revisión. Estudios de Psicología, 20(63-64), 147-161. Recuperado de https://dialnet.unirioja.es/servlet/articulo?codigo=1299663

Perrichi, C. (1986). El niño enfermo. Barcelona: Herder.

Plan Esperanza brinda atención oncológica integral a niños con cáncer del INEN. (16 de febrero de 2015). Andina. Recuperado de

http://www.andina.com.pe/agencia/noticia-plan-esperanza-brinda-atenciononcologica-integral-a-ninos-cancer-del-inen-543589.aspx

Rateau, P., y Lo Monaco, G. (2013). La Teoría de las Representaciones Sociales: Orientaciones Conceptuales, campos de aplicaciones y métodos. Revista CES Psicología, 6(1), 22-42. Recuperado de http://revistas.ces.edu.co/index.php/psicologia/article/view/2615

Rodriguez, E.; Dunn, M.; Zuckerman, T.; Vannatta, K, Gerhardt, C y Compas, B. (2012) Cancer-related sources of stress for children with cancer and their parents. Journal of PediatricPsychology, 37(2), 185-197. Recuperado de http://vkc.mc.vanderbilt.edu/stressandcoping/wp-content/uploads/2014/05/J.Pediatr.-Psychol.-2012-Rodriguez-185-97.pdf

Rodríguez, G., Gil, J. y García, E. (1999). Metodología de la investigación cualitativa. 
Málaga: Aljibe.

Rodriguez, J. y Neipp, M. (2008). Manual de Psicología Social de la Salud. Madrid: Síntesis.

Rojas, P. (2005) Duelo anticipatorio en padres de niños con cáncer (tesis para optar el título profesional de Licenciado en Psicología). Pontificia Universidad Católica del Perú.

Rozema H., Völlink, T. y Lechner, L. (2008). The role of illness representations in coping and health of patients treated for breast cancer. Wiley InterScience, 18(8), 849-857. doi: 10.1002/pon.1488.

Ruda, M.L. (2001). Representaciones acerca del cáncer y su origen en padres de niños diagnosticados con esta enfermedad. Revista de Psicología de la PUCP, 19(1), 151-201. Recuperado de http://revistas.pucp.edu.pe/index.php/psicologia/article/view/3625

Ruda, M.L. (2009). Representaciones infantiles de la enfermedad: variaciones según edad, grado de instrucción y nivel socioeconómico. Revista de Psicología de la PUCP, 27(1), 111-146. Recuperado de http://revistas.pucp.edu.pe/index.php/psicologia/article/view/247

Sánchez, T., Llano, D. y Guerrero, E. (2013). Adaptación al Duelo Anticipado de padres de escolares con Leucemia Linfoblástica Aguda. Hospital Nacional Almanzor Aguinaga Asenjo. Acc Cietna, 1(1), 13-19. Recuperado de http://www.usat.edu.pe/files/revista/acc-cietna/2013-I/articulo_2.pdf

Salguero, K. (2014). Estrategias que utilizan padres y madres durante el proceso de diagnóstico y tratamiento de sus hijos con Leucemia. (Tesis de Licenciatura) Universidad Rafael Landívar.

Silva, G. (2012). Las vivencias de niños hospitalizados. Lima: IEP.

Sloper, P. (2000). Predictors of distress in parents of children with cancer: a prospective study. Journal of Pediatric Psychology, 25(2), 79-91. Recuperado de http://jpepsy.oxfordjournals.org/content/25/2/79.long

Streisand, R., Braniecky, S.; Tercyak, K. y Kazak, A. (2001). Childhood illness-reated parenting stress: the pediatric inventory for parents. Journal of pediatric psychology, 26(3), 155-162. Recuperado de http://jpepsy.oxfordjournals.org/content/26/3/155.long

Tavera, M. (2012). Representaciones del VIH/SIDA y percepción de riesgo en adolescentes de nivel socioeconómico bajo (tesis de maestría). Pontificia Universidad Católica del Perú.

Tremolada, M., Bonichin, S., Altoè, G., Pillon, M., Carli, M. y Weisner, T. (2011). Parental perceptions of health-related quality of life in children with leukemia in the second week after the diagnosis: a quantitative model. Support Care Cancer, 1(1), 591-598. doi: 10.1007/s00520-010-0854-5.

Trujano, R., Vega, Z., Nava, C., y Saavedra, K. (2011). Interacción médico-paciente y su relación con el control del padecimiento en enfermos crónicos. Liberabit. Revista de Psicología, 17(2), 223-230. Recuperado de http://www.redalyc.org/articulo.oa?id=68622584011

Yeh, C. (2001). Gender differences of parental distress in children with cáncer. Journal of Advanced Nursing, 38(6), 598-606. Recuperado de http://onlinelibrary.wiley.com/doi/10.1046/j.1365-2648.2000.02227.x/abstract

Vrijmoet-Wiersma, C.; van Klink, J.; Kolk, A.; Koopman, H.; Ball, L. y Egeler, R. (2008). Assessment of parental psychological stress in pediatric cancer. Journal of Pediatric Psychology, 33(7), 694-706. Recuperado de http://www.ncbi.nlm.nih.gov/pubmed/18287109 
Wagner, W. y Hayes, N. (2011). El discurso de lo cotidiano y el sentido común: La teoría de las representaciones sociales. (F. Flores, Ed.) México: Anthropos.

Weiner, B. (1992). Human Motivation: metaphors, theories, and research. London: Sage Publications.

Wolfe-Christensen, C., Mullins, L., Fedele, D., Rambo, P., Eddington, A. y Carpentier, M. (2010). The Relation of Caregiver Demand to Adjustment Outcomes in Children With Cancer: The Moderating Role of Parenting Stress. Children's Health Care, 39(2), 108-124. Recuperado de http://www.tandfonline.com/doi/abs/10.1080/02739611003679881

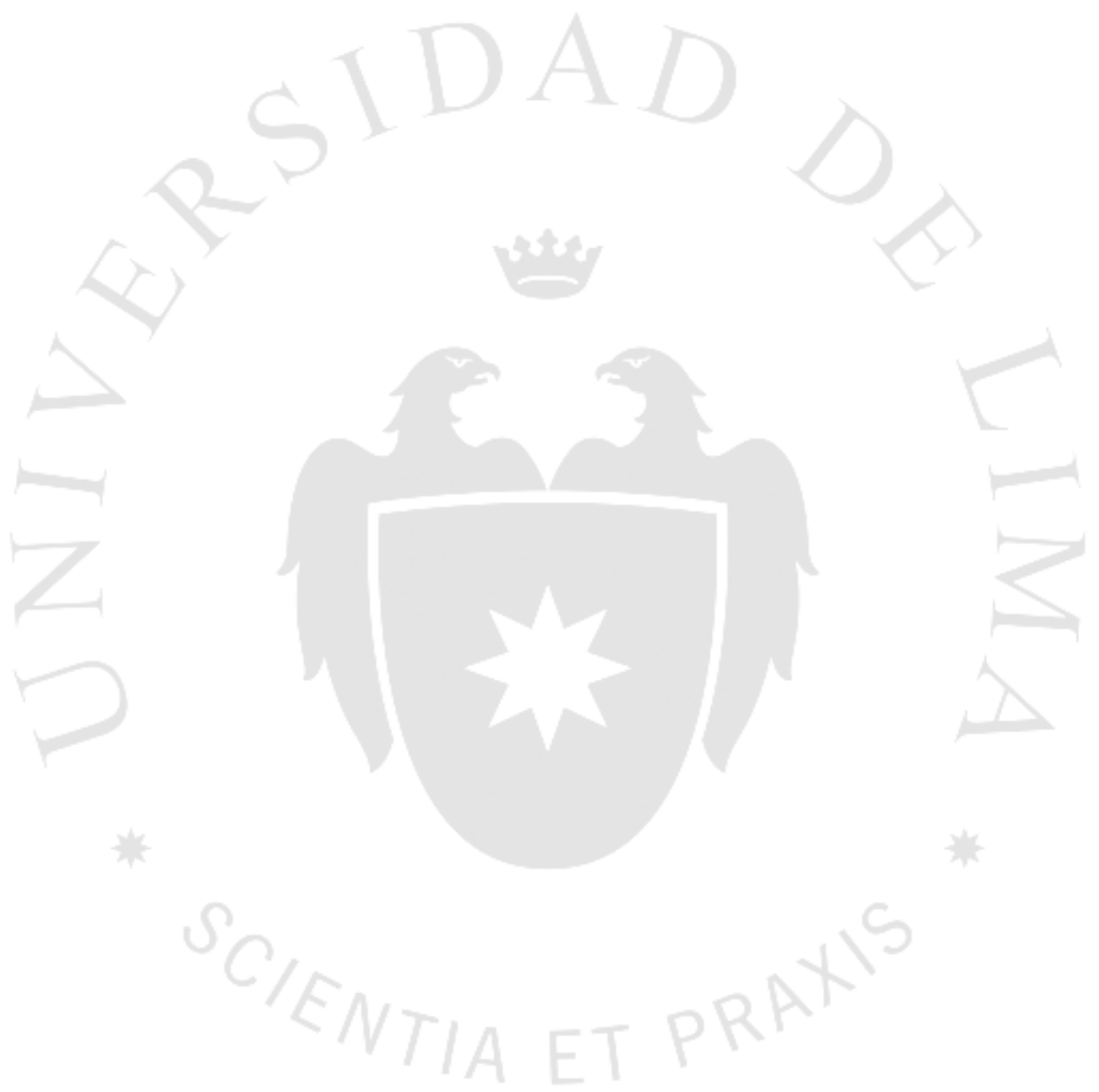




\section{BIBLIOGRAFÍA}

American Psychological Association. (2010). Publications manual of the American Psychological Association. Washington, DC: American Psychological Association.

Anderzén, A., Sorlie, V., Gustafsson, K., Olsson, M. y Kihlgren, M. (2015). Fear in children with cancer: observations at an outpatient visit. Journal of Child Health Care, 12(3), 191-208. Recuperado de http://www.ncbi.nlm.nih.gov/pubmed/18678582

Arabiat, D., Alqaissi, N. y Hamdan-Mansour, R. (2011). Children's knowledge of cancer diagnosis and treatment: Jordanian mothers'perceptions and satisfaction with the process. International Nursing Review, 58(4), 443-449. Recuperado de http://www.ncbi.nlm.nih.gov/pubmed/22092322

Björk, M., Nordström, B. y Hallström, I. (2006). Needs of Young Children With Cancer During Their Initial Hospitalization: An Observational Study. Journal of Pediatric Oncology Nursing, 23(4), 210-219. Recuperado de http://www.ncbi.nlm.nih.gov/pubmed/16766686

Cabrera, P., Urrutia, B., Vera, V., Alvarado, M. y Vera-Villarroel, P. (2005). Ansiedad y Depresión en Niños Diagnosticados con Cáncer. Revista de Psicopatología y Psicología Clínica, 10(2), 115-124. Recuperado de http://aepcp.net/arc/02.2005(2).Cabreraetal.pdf

Charmaz, K. (2006). Constructing grounded theory: A practical guide through qualitative analysis. London: Sage Publications.

Chau, C., Morales, H. y Wetzell, M. (2002). Estilos de afrontamiento y estatus performance en un grupo de pacientes oncológicos hospitalizados. Revista de Psicología de la PUCP, 20(1), 93-131. Recuperado de http://revistas.pucp.edu.pe/index.php/psicologia/article/view/3703

Clunies-Ross, C. y Lansdown, R. (1998). Concepts of death, illness and isolations found in children with leukaemia. Child Care Health Development, 14(6), 373386. Recuperado de http://www.ncbi.nlm.nih.gov/pubmed/3228962

Crespo E. y Freire, J. La atribución de responsabilidad: de la cognición al sujeto. Psicología \& Sociedade, 26(2), 271-279. Recuperado de http://www.scielo.br/pdf/psoc/v26n2/a04v26n2.pdf

Guardia, J. (2010). Ansiedad y afrontamiento en cuidadores de pacientes con esquizofrenia (tesis para optar el título profesional de Licenciado en Psicología). Pontificia Universidad Católica del Perú.

Lalljee, M. (1981). Teoría de la atribución y análisis de las explicaciones. Estudios de Psicología, 12(1), 47-62. Recuperado de https://dialnet.unirioja.es/servlet/articulo?codigo $=65857$

Lobato-Junior, A. (2013). Representaciones sociales y didáctica: construcción teórica de un espacio común. Magis. Revista Internacional de Investigación en Educación, 5(11), 277-295. Recuperado de http://revistas.javeriana.edu.co/index.php/MAGIS/article/view/5648

Marcos, C. (2010). Representaciones mentales de la paternidad en padres varones adolescentes (tesis para optar el título profesional de Licenciado en Psicología). Pontificia Universidad Católica del Perú.

Marinelli, F. (2013). Representaciones de apego y sensitividad paterna en padres de hijos en edad preescolar (tesis para optar el título profesional de Licenciado en Psicología). Pontificia Universidad Católica del Perú. 
Méndez, X., Orgilés, M., López-Roig, S. y Espada, J. (2004). Atención psicológica en el cáncer infantil. Psicooncología, 1(1), 139-154. Recuperado de http://revistas.ucm.es/index.php/PSIC/article/view/17206

Mendez, F., Ortigosa, J. y Quiles, M. (2003). Manual de Psicología de la salud con niños, adolescentes y familia. Madrid: Ediciones Pirámide.

Mora, M. (2002). La teoría de las representaciones sociales de Serge Moscovici. Athenea Digital, 1(2), 1-25. Recuperado de http://www.raco.cat/index.php/Athenea/article/viewFile/34106/33945

Palacios-Espinosa, X. y González, M. (2015). Las representaciones sociales del cáncer y de la quimioterapia en la familia del paciente oncológico. Avances en Psicología Latinoamericana, 33(3), 497-515. Recuperado de http://revistas.urosario.edu.co/index.php/apl/article/viewFile/3287/3037

Polaino-Lorente, A. y Del Pozo, A. (1991). Modificación de la ansiedad-rasgo y la ansiedad-estado mediante un programa de intervención psicopedagógica en niños cancerosos hospitalizados. Revista Complutense de Educación, 2(3), 419429. Recuperado de http://revistas.ucm.es/index.php/RCED/article/view/RCED9191330419A

Robert V., Álvarez, C., y Valdivieso, F. (2013). Psicooncología: Un modelo de intervención y apoyo social. Revista Médica Clínica Las Condes, 24(2), 677684. Recuperado de https://www.clinicalascondes.cl/Dev_CLC/media/Imagenes/PDF\%20revista\%20 médica/2013/4\%20julio/14_Ps.-Ver-|nica-Robert-M.pdf

Rodríguez-Marín, J., Pastor, A. y López-Roig, S. (1993). Afrontamiento, apoyo social, calidad de vida y enfermedad. Psicothema, 5(1), 349-372. Recuperado de http://www.psicothema.com/pdf/1148.pdf

Rodríguez-Zoya, L. y Rodríguez-Zoya, P. (2014). El doble vínculo entre representaciones sociales y comunicación social. Palabra Clave, 18(3), 905-937. Recuperado de http://www.redalyc.org/pdf/649/64941029012.pdf

Ruda, M.L. (2013). Memoria de las Jornadas de Psicooncología 2009 - 2012. Encuentros, retos y esfuerzos compartidos. Lima: Fondo Editorial de la Pontificia Universidad Católica del Perú.

Sistema Integral de Salud. (2016). SIS-Gratuito. Recuperado de http://www.sis.gob.pe/Portal/productos/sisgratuito/index.html

Scopa, L. (2011). Representaciones del cáncer en adolescentes que sufren dicha enfermedad (tesis para optar el título profesional de Licenciado en Psicología). Lima: Pontificia Universidad Católica del Perú.

Torre, M. (2015). Representaciones del cáncer en jóvenes con y sin esta enfermedad (tesis para optar el título profesional de Licenciado en Psicología). Pontificia Universidad Católica del Perú.

Vidal y Benito, M. (2012). Psiquiatría y psicología del paciente con cáncer. Buenos Aires: POLEMOS.

Zárate, L., Montero, J. y Gutierrez, M. (2006). Relación entre el estrés parental y el del niño preescolar. Psicología y Salud, 16(2), 171-178. Recuperado de http://www.redalyc.org/pdf/291/29116206.pdf 


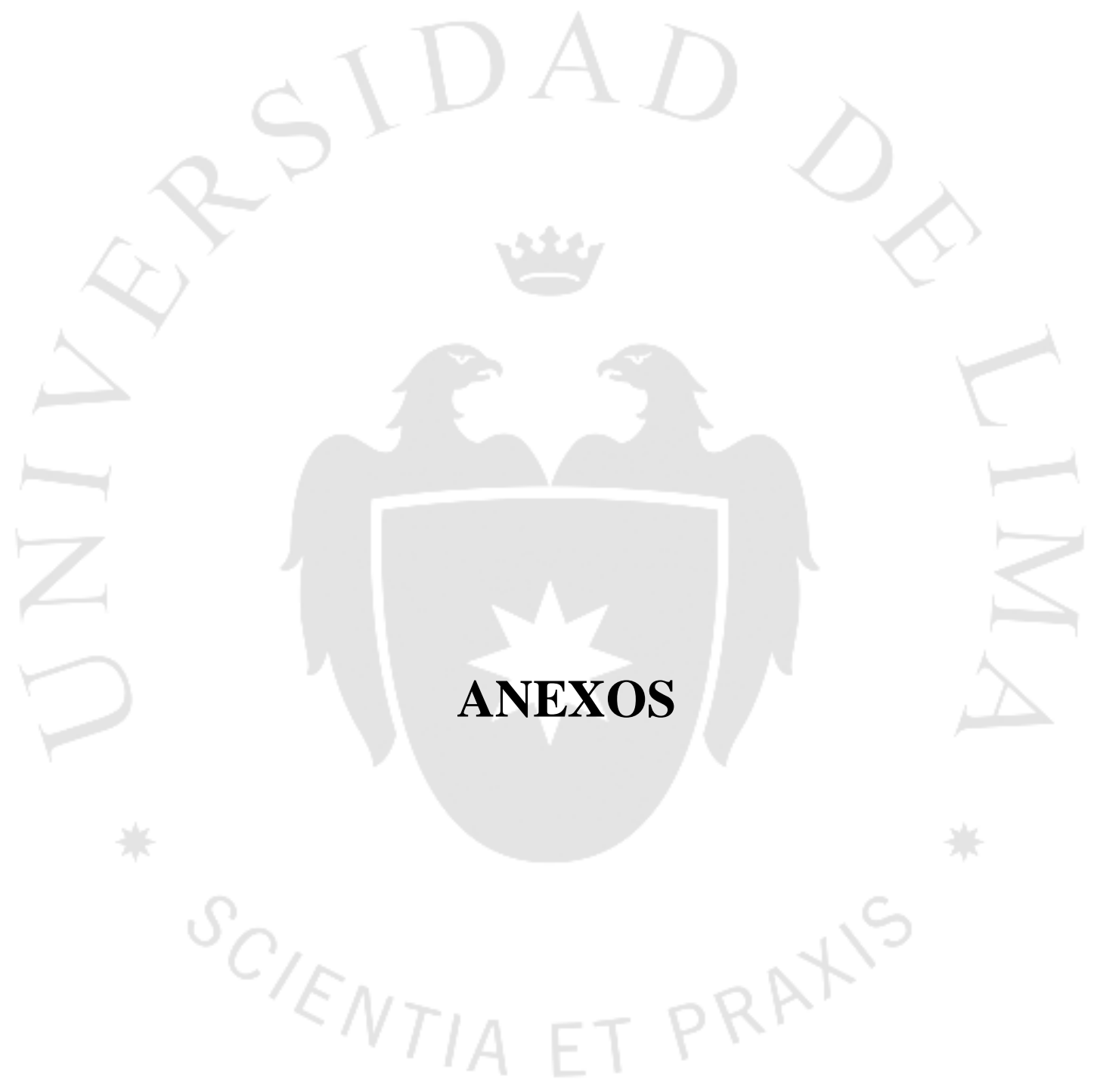




\section{ANEXO 1: Guía de preguntas}

\section{Identidad}

Para usted ¿qué es la Leucemia?

Lo que sabe de la Leucemia ¿cómo lo aprendió?

Cuando su hijo se sentía mal ¿qué se imaginaba que podía ser?

Antes de saber que su familiar tenía Leucemia ¿había escuchado hablar de esa enfermedad? ¿y ahora qué piensa?

\section{Causas}

¿De dónde cree usted que viene la Leucemia? ¿Cómo se origina?

¿Por qué cree usted que a su familiar le dio Leucemia?

¿Cuáles son los determinantes cree usted favorecieron la aparición de la enfermedad?

\section{Consecuencias}

¿De qué modo esta enfermedad afecta en la vida de su hijo?

¿Cómo reacciona su cuerpo frente a ella?

¿Cómo cree que será la vida de su hijo en los próximos meses?

¿Cómo cree que será la vida de su hijo en los próximos años?

\section{Posibilidades de cura}

¿Cómo se imagina que será el proceso de esta enfermedad?

¿Qué factores podrían influir en ella en términos del tratamiento y su evolución?

¿Considera que esta enfermedad puede ser curada? ¿Por qué?

¿Qué puede hacer usted al respecto? 


\section{ANEXO 2: Consentimiento informado}

El propósito de esta ficha de consentimiento es proveer al participante en esta investigación una clara explicación de la naturaleza de la misma, así como de su rol en ella como participante. La presente investigación es conducida por Maria Paula Colmenares Morelli, de la Universidad de Lima. La meta de este estudio es explorar las representaciones de la Leucemia en padres de niños diagnosticados con esta enfermedad.

Si usted accede a participar en este estudio, se le pedirá responder un cuestionario y un conjunto de preguntas en una entrevista. Esto tomará aproximadamente $\underline{60}$ minutos de su tiempo. Lo que conversemos durante estas sesiones se grabará, de modo que el investigador pueda transcribir después las ideas que usted haya expresado.

La participación en este estudio es estrictamente voluntaria. La información que se recoja será confidencial y no se usará para ningún otro propósito fuera de los de esta investigación. Sus respuestas a la entrevista serán codificadas usando un número de identificación y por lo tanto, serán anónimas. Una vez trascritas las entrevistas, las grabaciones o videos se destruirán.

Si tiene alguna duda sobre este proyecto, puede hacer preguntas en cualquier momento durante su participación en él. Igualmente, puede retirarse del mismo en cualquier momento sin que eso lo perjudique en ninguna forma. Si alguna de las preguntas durante la entrevista le parecen incómodas, tiene usted el derecho de hacérselo saber al investigador o de no responderlas.

Desde ya le agradecemos su participación.

Acepto participar voluntariamente en esta investigación, conducida por Maria Paula Colmenares Morelli. He sido informado (a) de que la meta de este estudio es explorar las representaciones de la Leucemia en padres de niños diagnosticados con esta enfermedad.

Me han indicado también que tendré que responder a un cuestionario y a un conjunto de preguntas en una entrevista, lo cual tomará aproximadamente $\underline{60}$ minutos.

Reconozco que la información que yo provea en el curso de esta investigación es estrictamente confidencial y no será usada para ningún otro propósito fuera de los de este estudio sin mi consentimiento. He sido informado de que puedo hacer preguntas sobre el proyecto en cualquier momento y que puedo retirarme del mismo cuando así lo decida, sin que esto acarree perjuicio alguno para mi persona. De tener preguntas sobre mi participación en este estudio, puedo contactar a Maria Paula Colmenares Morelli al teléfono $\underline{948871439 .}$

Para respuestas a las preguntas sobre los derechos de los participantes contactar con el Presidente del Comité Institucional de Ética en Investigación (CIEI) del INEN: Arístides Juvenal Sánchez Lihón, y los siguientes datos del CIEI: teléfono 201-6500, anexo 3001 y correo electrónico: comité_etica@inen.sld.pe.

Entiendo que una copia de esta ficha de consentimiento me será entregada, y que puedo pedir información sobre los resultados de este estudio cuando éste haya concluido. Para esto, puedo contactar a Maria Paula Colmenares Morelli al teléfono anteriormente mencionado. 


\section{ANEXO 3: Libro de códigos}

\begin{tabular}{ll}
\hline \multicolumn{1}{c}{ Categoría 1 } & \multicolumn{1}{c}{ Identidad } \\
\hline Subcategoría 1.1 & Conceptualización \\
Subcategoría 1.2 & Recepción de la información \\
Subcategoría 1.3 & Explicación previa de la enfermedad \\
Subcategoría 1.4 & Conocimientos previos \\
\hline \multicolumn{1}{c}{ Categoría 2 } & Causas \\
\hline Subcategoría 2.1 & Biológico \\
Subcategoría 2.2 & Medio ambiente \\
Subcategoría 2.3 & Condiciones sanitarias \\
Subcategoría 2.4 & Alimentación \\
Subcategoría 2.5 & Dinámica familiar \\
Subcategoría 2.6 & Golpe \\
Subcategoría 2.7 & Místico-religioso \\
Subcategoría 2.8 & Azar \\
\hline Categoría 3 & A nivel emocional \\
\hline Subcategoría 3.1 & A nivel conductual \\
Subcategoría 3.2 & A nivel físico \\
Subcategoría 3.3 & Consecuencias \\
\hline
\end{tabular}

\section{Categoría 4}

Subcategoría 4.1

Proceso de enfermedad

Subcategoría 4.2

Gravedad

Subcategoría 4.3

Respuesta

Subcategoría 4.4

Factores de influencia

\section{Categoría 5}

Subcategoría 5.1

Subcategoría 5.2

Posibilidad de cura

Medicina convencional

Factor místico 


\section{Otros documentos}

\section{DATOS DE HISTORIA CLÍNICA}

- Número de historia

- Lugar de Procedencia

- Diagnóstico

- Tiempo de Diagnóstico

- Número de Hospitalización

- Tiempo Actual de Hospitalización

- Área de Hospitalización

- Tipo de Tratamiento 


\section{FICHA SOCIODEMOGRÁFICA}

Edad:

Sexo
a. Femenino
b. Masculino

Lugar de Nacimiento:

Lugar de Procedencia:

Lugar de Residencia:

Tiempo de Residencia en Lima:

\section{Estado Civil}
a. Soltero
b. Conviviente
c. Casado
d. Viudo
e. Divorciado
f. Separado

\section{Grado de Instrucción}
a. Primaria incompleta
b. Primaria completa
c. Secundaria incompleta
d. Secundaria completa
e. Técnico
f. Superior incompleta
g. Superior completa

Ocupación:

Religión: 